\title{
Slavery by a New Name: \\ Children, Childhood, and Forced Labour in Colonial \\ Ghana, 1855-1914
}

by

\section{Catherine Koonar}

A thesis submitted to the Faculty of Graduate and Postdoctoral Affairs in partial fulfillment of the requirements for the degree of:

Master of Arts

in

History with Specialization in African Studies

Carleton University

Ottawa, Ontario

(C) 2014

Catherine Koonar 


\begin{abstract}
The topic of child labour receives a great deal of attention from humanitarian and nongovernmental organizations, but from a historical perspective, child labour has been under researched and under studied. Looking specifically at colonial Ghana, this study analyzes the effects of anti-slavery legislation and the presence of the Basel Mission Society on the lives of African children. It argues that as the institution of slavery went into decline in West Africa, the forced labour of children actually became more common. In its analysis of children and forced labour, this thesis will make clear that there is, in fact, a great deal of insight to be gained from including children in the narrative. In doing so, assumptions about key themes such as the racialization of labour, the gender division of labour, and the capacity of children to negotiate and shape the terms of their labour can be complicated.
\end{abstract}




\section{Acknowledgments}

This project, and my graduate studies more generally, would not have been possible without the support, guidance, and critiques of my supervisor, Dr. Audra Diptee. Audra has always believed in me, even when I did not believe in myself. She has taught me how to be a better writer, a better scholar, and a more confident person. Audra has been an invaluable mentor, friend and confidant throughout my graduate school experience and I owe her a great deal of gratitude for the unconditional support and well-intentioned, if sometimes convoluted, sports metaphors that got me through the research and writing process.

I also owe a tremendous amount of gratitude to Dr. James Miller for his years of support. Dr. Miller has offered critiques of papers, articles and, most importantly, of this thesis. Without his help and direction this work would not have been possible. I am also extremely grateful for his support of my future graduate school plans and his constant encouragement. I would also like to thank Dr. Susanne Klausen for her help and advice throughout my Master's degree, and Dr. Jennifer Evans for her guidance and assistance as Graduate Chair. I am also extremely grateful to Joan White for her assistance in navigating various administrative and bureaucratic channels over the last two years.

I would also like to acknowledge the support I received from the Peter Browne Memorial Scholarship. It was an honour to receive the award. This scholarship made it possible for me to purchase image rights from the Basel Mission Archive which have 
been included in my thesis and for me to focus more completely on finishing the writing and editing process.

I would like to thank my friends, family and co-workers for their constant support and their ability to keep my mind off of looming deadlines and for motivating me when those deadlines could no longer be avoided. In particular, Alexis McEwan, David Thompson, Arpita Bajpeyi, Melissa Armstrong, Yvonne Langen, Shelly McGarry, Milaine Bastien, Yan Lauzon, and my parents, Colin and Carol. Your love, encouragement, and friendship have enabled me to step away from my academic work and see the bigger picture when necessary. I owe a special thank you to Arpita for her kindness, companionship, and her invaluable help during the editing process.

Most importantly, I need to thank Pardeep for his endless love, support, friendship, encouragement, inspiration, and reassurance. This work is dedicated to him. It would have been impossible to complete without his love, even if, at times, it was of the "tough" variety 


\section{Table of Contents}

Abstract

Chapter One - Children, Childhood, and Emancipation Legislation in Colonial

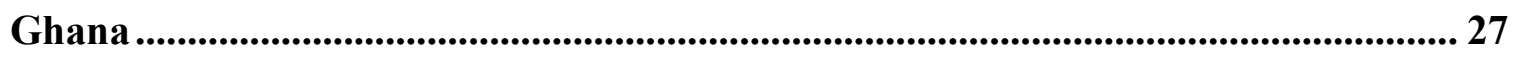

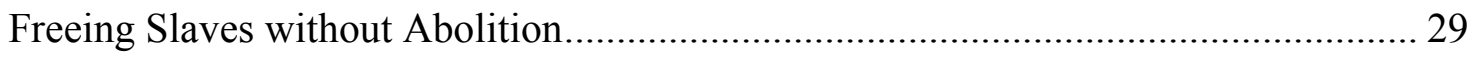

Consequences of the Emancipation Ordinance for African Children ......................... 36

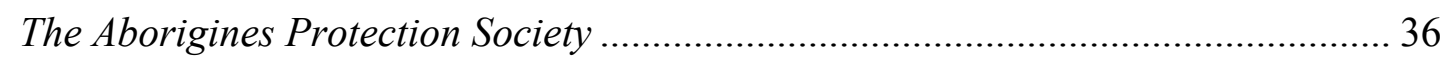

The Master and Servant Ordinance: Slave Children and the Colonial Courts............. 43

Chapter Two - Saving the Children from "Perdition": Child Labour and the Basel

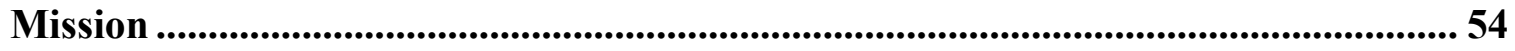

Historical Context: Early Colonial Ghana and the Basel Mission ............................. 56

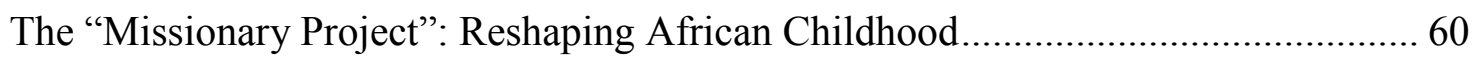

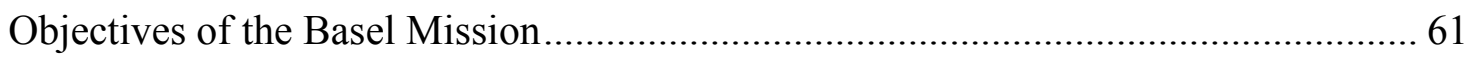

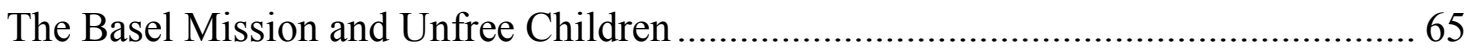

Child Labour at Basel Mission Schools .................................................................... 72 


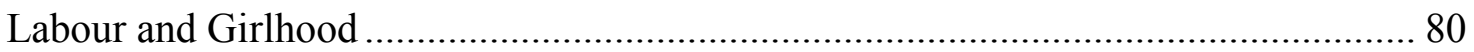

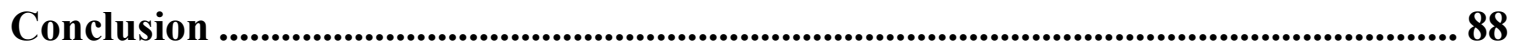

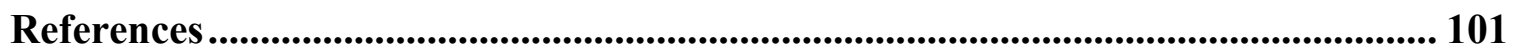

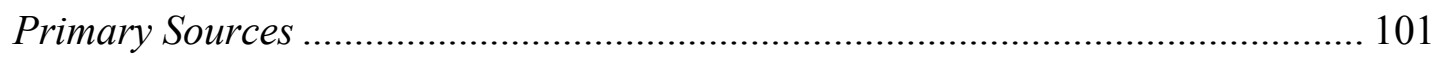

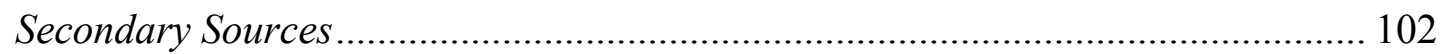




\section{Introduction}

In historical literature to date, children and childhood are often left outside the scholarly discourse addressing the history of Africa, and African labour history in particular. Instead, this topic receives a great deal of attention from humanitarian and nongovernmental organizations like the Anti-Slavery Society and Save the Children International. Though child labour played a critical role in colonial economies, the field of African history has continued to treat child workers as largely "invisible" and as a result child labour has been under researched and under studied. ${ }^{1}$ That this topic has been so understudied has, no doubt, limited our current understanding of the forces of race, agency, gender, and patriarchy and the ways in which these factors influenced the lives and actions of African children. This thesis will argue that as the institution of slavery went into decline in West Africa, the forced labour of children actually became more common. This study looks particularly at colonial Ghana and the effects of anti-slavery legislation and the presence of European mission societies on the lives of African children.

According to Audra Diptee and Martin Klein, "the obvious starting place for a study on African children is an analysis of the ways in which African childhoods were

\footnotetext{
${ }^{1}$ One significant exception has been Beverley Grier's pioneering work Invisible Hands (Beverley Grier, Invisible Hands, (2006) which looks at child labour in colonial Zimbabwe.
} 
socially constructed, perceived, and understood in varying contexts." ${ }^{2}$ In its analysis of children and forced labour, this thesis will make clear that there is, in fact, a great deal of insight to be gained from including children in the narrative. In doing so, assumptions about key themes such as the racialization of labour, the gender division of labour, and the capacity of children to negotiate and shape the terms of their labour can be complicated.

Mission societies maintained a fairly constant, if isolated, presence on the coast of West Africa for at least a century prior to the British annexation of the Gold Coast Colony and Protectorate. Missionaries were generally against the institution of slavery, but they were often forced to take a pragmatic approach to the practice because free labour was difficult to come by. This was particularly true in the interior of the colony where the Basel Mission established mission stations and villages. Even Following the Emancipation Ordinance in 1874, the Basel Mission often required the labour of children who were enrolled in their schools or were members of the congregation.

The ineffectiveness of anti-slavery legislation was also a factor in the experience of children in the colony. Children who did manage to challenge their position as slaves in the colonial courts were often placed back in the care of their convicted masters because the colonial government was incapable of finding appropriate apprenticeships for

\footnotetext{
${ }^{2}$ Audra A. Diptee and Martin A. Klein, "African Childhoods and the Colonial Project," Journal of Family History. 35 (2010), 35.
} 
them. The enforcement of these laws was even more inconsistent in the interior where colonial officials were stretched extremely thin. ${ }^{3}$

Using the British Parliamentary Papers and the Basel Mission correspondence records, this study brings the experience of African children to the fore. It analyzes the lengths to which enslaved children needed to go in order to achieve the freedom they had theoretically been granted in 1874. It also looks at the experience of children in the interior of the colony where the Basel Mission set up its stations and schools. In both instances insight can be gained about the lives of children in colonial Ghana and add nuance to the narratives of labour history and the history of childhood in Africa.

\section{Childhood Theory}

Allison James and Adrian James, the foremost contemporary theorists on childhood, put forward, in their 2004 book Constructing Childhood, what they term the theory of 'cultural politics of childhood' in which they suggest that while childhood is a universal experience in the 'human life-course,' it should still be viewed as problematic and not be simply defined as a unique biological phase defined by numerical age or physical characteristics. Rather, they argue, childhood has been shaped and institutionalized differently in different times and places throughout history and as result it has acquired very different meanings according to context and circumstance. ${ }^{4}$

\footnotetext{
${ }^{3}$ Trevor Getz, Slavery and Reform in West Africa and Trevor Getz and Liz Clarke, Abina and the Important Men.

${ }^{4}$ Allison James \& Adrian James. Constructing Childhood.
} 
The history of African children and the ways in which African childhoods have been constructed remain an understudied area. In fact, African children are generally addressed in a cursory fashion even in those studies that offer a global history of childhood. ${ }^{5}$ For the purposes of this thesis, it has been important to ask questions about the limitations of this theory in the African context: Does this theory of childhood apply in the African context? How have race and colonialism affected ideas about childhood in Africa? Does a distinct African childhood exist at all? In the European context, notions of childhood are predicated on paternalistic ideals, but in Africa, there are additional competing variables such as race, colonialism and indigenous notions of childhood. As a result, theories of childhood must be applied with caution and the particularities of the African context should be taken into account in any study of childhood in Africa.

In order to develop a more nuanced understanding of childhood, James, Jenks and Prout argue that studies which foreground the social agency of children are necessary. One aspect of this is the differentiation between 'children' and 'childhood.' Childhood is the theoretical framework within which the experiences of children can be studied and analyzed and the manner in which the aggregate of these experiences enables us to conceptualize notions about the experience of being a child. This includes an understanding of how children deal with their circumstances, which can be gained through studying their daily lived experiences, their understanding of these experiences,

\footnotetext{
${ }^{5}$ See, for example, Peter Stern, Childhood in World History (New York: Routledge, 2006) and Jennifer Helgren \& Colleen A. Vasconcellos Girlhood: A Global History (New Brunswick, N.J.: Rutgers University Press, 2010).
} 
their interaction with each other as well as with adults, and their strategies of action. ${ }^{6}$ As James and Prout suggest:

Children might employ a variety of models of agency within and between different social environments... the possibility [exists] that children locate themselves flexibly and strategically within particular social contexts and that, through focusing on children as competent, individual social actors, we might learn more about the ways in which 'society' and 'social structure' shape social experiences and are themselves refashioned through the social action of members. ${ }^{7}$

The social constructionist viewpoint, put forward by James, Jenks and Prout, rejects the notion of childhood as being determined by some fixed essential nature and, instead, contends that ideas of childhood are a "way of looking, a category of thought, a representation." ${ }^{\prime 8}$ This view came into existence through discourses that created their own objects within society and insisted that childhood could be constructed in diverse and shifting ways and, as James and James suggest, it maintains that childhood is "common to all children but also fragmented by the diversity of children's everyday

\footnotetext{
${ }^{6}$ Allison James, Chris Jenks \& Alan Prout. Theorizing Childhood (Cambridge, UK: Polity Press in Association with Blackwell Publishers Ltd., 1998), 138.

${ }^{7}$ Allison James \& Alan Prout. Constructing \& Reconstructing Childhood: Contemporary Issues in the Sociological Study of Childhood (London; New York: Falmer Press, 1990), 78.

${ }^{8}$ James \& Prout. 139-140.
} 
lives." It varies considerably across and between cultures as well as in relation to the everyday engagement of children with the societies in which they live.

James and James have suggested that there are three factors that contribute to the construction of childhood and explain why a universal definition is impossible. Firstly, ideas and meanings of childhood are formed by both adults and by children. Although children are assigned their social position by adults and are often defined in opposition to the idea of what it means to be an adult (physically, emotionally, intellectually) children also exercise agency and negotiate their own position in society. ${ }^{10}$ Secondly, culturally determined ideas about childhood are used to construct legal definitions and as a result, childhood is shaped by tradition, and the formation of social and legal codes. Thirdly, children react differently to ideas of childhood that are forced upon them and, thus, the idea of childhood is not something that can be conceived of without taking into account the actions of children themselves. ${ }^{11}$

\section{Historiography of Childhood}

While the presently accepted theory of childhood was first articulated in the late 1990s and early 2000s by sociologists Allison James, Adrian James, Chris Jenks and Alan Prout, it has a long history as an academic subject. Historians had previously dealt with

\footnotetext{
9 James \& James. Constructing Childhood: Theory, Policy and Social Practice (New York: Palgrave Macmillan, 2004).13.

${ }^{10}$ Chris Jenks has argued that we cannot imagine the child except in relation to a conception of the adult (ie. It is negatively defined) and it becomes difficult to contextualize the adult without starting with the idea of the child. He states that, "the child is familiar to us and yet strange" and that "he or she inhabits our world and yet seems to answer to another." In Chris Jenks. Childhood Key Ideas. (London; New York: Routledge, 2006).

${ }^{11}$ James and James. Constructing Childhood.
} 
ideas about childhood, but the concept itself was not clearly articulated until Theorizing Childhood was published in 1998 (followed by Constructing Childhood in 2004). The first critical engagement with ideas of childhood was in Philippe Ariès' work Centuries of Childhood; a Social History of Family Life in 1962 in which he wrote a history of childhood in early modern Europe. ${ }^{12}$ His central thesis was that attitudes toward childhood were not static, that they evolved and changed over time. For Ariès, childhood, as a concept and an accepted part of family life, came into existence in the seventeenth century. ${ }^{13}$ Centuries of Childhood is regarded as first book on the subject of childhood, and while it has received a significant amount of criticism since its publication, Ariès contribution is recognized as being profoundly important in that it identified childhood as a social construction, rather than a biological given. This social constructionist viewpoint is central to the concept of the 'cultural politics of childhood' articulated decades later in the work of James and James.

Ariès assertion that the medieval world did not recognize the existence of childhood (as a unique phase in the 'life course') has come under a significant amount of criticism from historians, sociologists and psychologists. ${ }^{14}$ There were serious objections to his methodological approach and his interpretation of the historical record, for example, Henry Hendrick contended, in a 1992 critique, that Ariès' work was flawed in the following ways:

\footnotetext{
${ }^{12}$ Philippe Ariès (1914-1984) was a French Medievalist and historian of the family and childhood who is most widely known for his work regarding the changing western attitudes toward death.

${ }^{13}$ Philippe Aries. Centuries of Childhood: A Social History of Family Life Translated by Robert Baldick, (New York: Vintage Books, 1962).

${ }^{14}$ See, for example, Jerome Kroll, "The Concept of Childhood in the Middle Ages." Journal of the History of The Behavioral Sciences, 13, No. 4 (October 1977): 384-393. \& Shulamith Shahar, Childhood in the Middle Ages (London; New York: Routledge, 1990).
} 
Firstly, that his data are either unrepresentative or unreliable. Secondly that he takes evidence out of context, confuses prescription with practice, and uses atypical examples. Thirdly, that he implicitly denies the immutability of the special needs of children, for food, clothing, shelter, affection and conversation. Fourthly, that he puts undue emphasis on the work of moralists and educationalists while saying little of economic and political factors. ${ }^{15}$

Despite the (predominantly historical) objections to Ariès' work, the idea that childhood is something that is shaped and re-shaped over time is the crucial idea upon which sociologists like James, James, Jenks and Prout would later base their theory of childhood as being spatially and temporally contingent. The historical inaccuracies and methodological missteps, for which Centuries of Childhood has been criticized, are secondary to the conceptual notion of childhood as a category of thought and analysis that is socially constructed differently according to varying historical circumstances.

In the late 1980s, Leena Alenan argued that an ethnographic approach to the sociological study of childhood would help to show that children do, in fact, play a substantial role in shaping childhood through their everyday social relations. This change in thinking about the socialization of children, Alenan suggested, would contribute to children being seen not only as objects being socially acted upon, but as social actors in their own right, adding complexity to the sociological conception of childhood. As a

\footnotetext{
${ }^{15}$ Henry Hendrick, "Children \& Childhood," Journal of the Economic History Society 15 (Autumn 1992): $1-4$.
} 
result, childhood could be moved from its traditional micro-world of family and schooling and be placed within the context of central theoretical concerns of sociology more generally. Alenan regarded earlier ideas surrounding socialization as objectifying those undergoing the process and she argues that an ethnographic approach that stresses the agency of children is more promising as a method through which to understand childhood. $^{16}$

While Alenan's suggestion has been heeded by many sociologists interested in the concept of childhood, the broad framework of Ariès' work remains the foundation for contemporary work in childhood studies and his thesis (that ideas of childhood change and evolve over time) has provided scholars with a platform from which to engage in critical thinking about childhood and the ways in which it is conceived. His most important contribution, according to James and James, was that fact that he offered "a taste of cultural relativity across time" which made researchers aware of the diverse, rather than universal, nature of childhood. ${ }^{17}$

Two principles that James and James have developed, using Ariès work as their foundation, are firstly, that childhood cannot be regarded as unproblematic. It must be seen, instead, as a "particular cultural phrasing of the early part of the life course." And secondly, that children's experiences of being a child are shaped, but not defined, by

\footnotetext{
${ }^{16}$ Leena Alenan, "Rethinking Childhood," Acta Sociologica 31, 1 (1988): 60-61.

${ }^{17}$ James \& James. Constructing Childhood. 13.
} 
adults. Furthermore, their engagement with, and responses to, the adult world are even more important in shaping and constructing conceptions of childhood. ${ }^{18}$

Sociologists and historians, among other scholars, have used their ideas about childhood to study a wide range of topics including working children, the validity of the United Nations Declaration on the Rights of the Child (UNDRC), early childhood education and the effects of divorce on children. This suggests that the idea of 'cultural politics of childhood' works well in the European context; however, when it is applied in non-European contexts (particularly in the global south), it should be approached with skepticism and caution. Beverly Grier, who has used the theory to study child labour in colonial Zimbabwe, has acknowledged the significant contribution James and James' have made to the field of childhood studies, but she has also stressed the importance of identifying, and working within, the historical particularities of the African context. ${ }^{19}$

\section{Applying Childhood Theory in the African Context}

In arguing that childhood is a social construction and that there is no such thing as one single childhood (rather, that a multiplicity of childhoods exist) one encounters problems related to the globalization of childhood and children's rights, particularly in the wake of the United Nations Declaration on the Rights of the Child (UNDRC - 1989). The 'cultural politics of childhood' plays a key role in understanding this process because of its focus on the cultural factors that determine the different understandings of childhood

\footnotetext{
18 James \& James. Constructing Childhood. 13.

${ }^{19}$ Grier, Invisible Hands.
} 
within a given society at a given historical moment. The assertion that there exists a multiplicity of childhoods, however, also raises questions: In what ways, and under what circumstances, is being a 'child' a shared or common experience? How much does the experience of being a 'child' vary, and in what ways? ${ }^{20}$

The concept of the 'cultural politics of childhood' provides a framework within which questions like those above can be considered by drawing attention to the dynamic processes through which childhood is socially constructed. This theory is particularly useful in the study of African childhood because it allows for the study of children and the shaping of conceptions of childhood to be guided by local cultural assumptions, rather than by global notions of what childhood might be. In studying African childhood, it is important not to use western conceptions as the point of reference, but rather to use the theory of the 'cultural politics of childhood' to complicate current notions of African childhood. In the African context, this requires engagement with race, colonialism and patriarchy as affecting the construction of childhood, both in their influence on African children and in the ways that African children have negotiated their own ideas about their experiences within these paradigms.

As stated above, Chris Jenks contends that childhood has traditionally been negatively defined; meaning that it is defined by what it is not (adulthood), rather than by what it is. Given that western notions of childhood have been institutionalized legally and politically (in the UNDRC), it is important that African childhood be defined, as

\footnotetext{
${ }^{20}$ James \& James. Constructing Childhood.
} 
much as possible, according to what it is, and not by what it is perceived to be lacking in relation to western notions of childhood. ${ }^{21}$ For insight into the critique of progressive narratives in the African context we need not look further than Frederick Cooper's warning that evaluating Africa according to what they are supposedly lacking privileges the west and assumes that westerners have set the cultural and intellectual standard which Africa has failed to reach because of some kind of perceived inferiority. ${ }^{22}$ This is an important guide for the study of both contemporary African childhood and historical African childhood, particularly with regard to race, religion, colonialism, imperialism, patriarchy and (in contemporary terms) development and foreign aid.

Frederick Cooper, contends that any study of history that "confines the zigzags of time into linear pathways [and] tells a story of "progress" inevitably leaving Africans... on the side, lacking some crucial characteristic necessary to attain what is otherwise "universal" should be rejected outright. ${ }^{23}$ I would argue that the same is true of childhood studies. Any notion or definition of childhood that is applied in Africa, must take into account the unique particularities that make up the contemporary, and the historical, experiences of African children. Moreover, there is not one African childhood,

\footnotetext{
${ }^{21}$ The hesitance, and in some cases outright refusal, of various countries to sign on to the United Nations Declaration on the Rights of the Child is a good example of the intersection of theory and reality. The refusal of many countries to comply with various parts of the Declaration suggests that childhood is, indeed constructed, both spatially and temporally. The presence of these ambiguities is particularly evident in the response of developing countries due to the dominant influence of western notions of childhood throughout the Declaration and speaks to the need for continued research into the construction of childhood in the global south within the framework delineated by James et al.

${ }^{22}$ Frederick Cooper. "Postcolonial Studies and the Study of History" In Ania Loomba, Suvir Kaul, Matti Bunzl, Antoinette Burton \& Jed Esty, eds. Postcolonial Studies \& Beyond (Durham, N.C.: Duke University Press, 2005), 402.

${ }^{23}$ Frederick Cooper. “Africa's Past \& Africa's Historians.” Canadian Journal of African Studies 34, No. 2, (2000): 298-336. 298.
} 
but a multiplicity of African childhoods to be considered. Additionally, as noted by Cooper, "the best of social theory is historical to its core" and thus, theories of childhood must be, as James and James suggest, informed by the historical realities present within any given society at a given time. ${ }^{24}$

This thesis is informed by James, James' theory of childhood as a construction that is shaped and reshaped very differently according to time and space and guided by the methodological approach of Africanists like Cooper and Grier. It seeks to present varied voices and perspectives as well as highlight the range of experiences through which African children in colonial Ghana lived. This study also emphasizes the importance of including children in the narrative of African history, and inserting Africa into the narrative of the history of childhood. This approach aims to allow for a better understanding, not only of African history, but a more nuanced understanding of childhood. The concept of childhood, as articulated by James and James, is predicated on the historical work of Philippe Ariès and thus, future historical studies should be informed by the 'cultural politics' theory.

While the concept of childhood is not necessarily western, the current literature relies on assumptions derived from western understandings of childhood that have not factored in non-western ideas, social structures or cultural particularities. The theory of childhood and the study of children need to be advanced further by considering other factors, such as colonialism, race and competing notions of childhood within Africa.

\footnotetext{
${ }^{24}$ Cooper, “Africa's Past \& Africa’s Historians,” 310.
} 
Western notions of childhood should be applied with both caution and scepticism in any analysis that aims to explore African notions of childhood, Beverley Grier, through her exhaustive study of child labour in colonial Zimbabwe, has shown that this theory of childhood can work in the African context, provided that the researcher takes into account the particular social and cultural assumptions embedded within African societies, and the ways in which they differ from those of western societies. However, the assertion, by James and James, that a multiplicity of childhoods may exist, is also true in the African context.

While historians had been interested in some aspects of the lives of children for a long time, prior to the work of James, James, Jenks and Prout, a theoretical framework within which to study childhood did not exist. The work of sociologists of childhood has provided this framework and has allowed for more theoretically grounded historical studies that can test the limits of childhood theory in various contexts. A more nuanced understanding of global childhood appears to be dependent upon the further application of James and James' childhood theory and the ways in which its limits are tested and its parameters defined, and redefined, based on both historical and contemporary understandings of childhood.

In global studies of children and childhood, African children are generally discussed in a superficial manner and given this gap in the literature regarding childhood more broadly in Africa, it is important to ask why there has yet to be a great deal of work done on children and childhood. Wiseman Chirwa suggests three reasons for the invisibility of children with particular regard to their presence as labourers. The first is 
that the sources are not as numerous as they are for adults, second, the emotive nature of the term "child labour" can complicate the study of its history and "limit objective analysis of child labour as a scholarly subject," and third, the difficulty of defining child labour combined with the disguised forms that it often takes can lead to ambiguity. ${ }^{25}$ Beverley Grier adds two additional reasons why child labour has been understudied: it is linked to the invisibility of women, until recently, in African historiography and the ubiquity of the practice of child labour in Africa renders it invisible to researchers. ${ }^{26}$

To date, the most significant contribution to the history of African child labour has been Beverly Grier's work on colonial Zimbabwe. Her Invisible Hands is the first book length historical study to look at notions of childhood in Africa and the experience of children as labourers and has set an important standard for the fields of African labour history and childhood studies. In her analysis of children as social actors, Grier stresses the agency of children and their role in African labour dynamics and social processes. This thesis emphasizes the importance of studying the history of child labour and the experience of childhood by arguing that its inclusion in the study of African labour history can further complicate the narrative of childhood in Africa.

Other important contributions to the history of children and childhood have come from Gwynn Campbell, Benjamin Lawrance, Suzanne Miers, Joseph Miller, and Richard Roberts. ${ }^{27}$ Since 2009, three edited volumes have been published in which the

\footnotetext{
${ }^{25}$ Wiseman Chirwa, "Child and Youth Labour on the Nyasaland Plantations, 1890-1953," Journal of Southern African Studies 19, 4 (Dec. 1993): 662-680. 664.

${ }^{26}$ Grier, Invisible Hands, 6 .

${ }^{27}$ See: Gwynn Campbell, Suzanne Miers and Joseph C. Miller, eds, Children in Slavery Through the Ages (Athens, OH: Ohio University Press, 2009), Gwynn Campbell, Suzanne Miers and Joseph C. Miller, eds,
} 
experiences of child slaves throughout history have been explored. The essays in these studies range in geographic and temporal focus, but each essay attempts to flesh out features that made the experience of child slaves different from that of adults. This thesis builds on the work these scholars have done in order to complicate the narrative of slavery and forced labour in Africa.

\section{Historicizing Child Labour in Africa}

E. P. Thompson's The Making of the English Working Class has had a significant impact on the work of African labour historians. ${ }^{28}$ In the 1970 s, there was a concern with critiquing the conception of Africa as "being bound by some kind of tribalism" and "ending the search for a kind of African authenticity." 29 These changes in the way African labour histories were written enabled Africanists to address larger questions of greater theoretical importance. Frederick Cooper criticizes early scholarship by Africanist labour historians for following a teleological blueprint suggesting that everything Thompson discussed in his work led to the formation of the English working class. ${ }^{30}$ He argues that, rather than suggesting that Africans could also be workers, Africanists should also explore whether the meanings Africans "attached to work, the kinds of work groups in which they participated, and the notions they had of collectivity

Child Slaves in the Modern World (Athens, OH: Ohio University Press, 2011), Benjamin N. Lawrance and Richard L. Roberts, Trafficking in Slavery's Wake: Law and the Experience of Women and Children (Athens, OH: Ohio University Press, 2012).

${ }^{28}$ Frederick Cooper, "Work, Class and Empire: An African Historian's Retrospective on E. P. Thompson," Social History 20 (May, 1995): 235-241, 235.

${ }^{29}$ Cooper, "Work, Class and Empire," 236.

${ }^{30}$ Cooper, "Work, Class and Empire," 236. See also: Frederick Cooper, Struggle for the City: Migrant Labor, Capital and the State in Urban Africa (Beverly Hills, CA: Sage Publications, 1983). 
affected their actions in an era of capitalist intrusions." ${ }^{.31}$ To date, much of the history of labour in Africa has been concerned with the proletarianization of African workers, but it has largely excluded children. Although child labour in Africa is very much a contemporary concern, and has received attention from non-governmental organizations and human rights organizations like the International Labour Organization, the United Nations Children's Fund (UNICEF), and the Anti-Slavery Society, there is still much work to be done on its history.

\section{Methodology}

During the course of this research, I have employed a critical analysis of written and visual sources including government documents, reports and correspondence, missionary papers, reports and photographs, court documents, personal correspondence and newspaper articles. It has been important to recognize the "dominant" set of assumptions that are embedded in many documents produced in colonial Ghana and to attempt to read beyond them. These assumptions include the inherent racial, religious and intellectual superiority felt by Europeans and their underlying desire to "civilize" Africans and the imperialistic tendency held even by humanitarian and advocacy groups like the AntiSlavery Society and the Aborigines Protection Society.

Children did not keep diaries or personal records of the events of their lives or the nature of their enslavement. Some slaves did record their life stories during their

\footnotetext{
${ }^{31}$ Cooper, "Work, Class and Empire," 236 \& Bill Freund, The African Worker (Cambridge and New York: Cambridge University Press, 1988), 24.
} 
adulthood. These narratives included memories of their childhoods, but these are, of course, "filtered through later experiences." 32 There are some glimpses of the experience of children, but full accounts do not exist. Children's voices can be read indirectly in documents like newspaper articles, court disputes, personal correspondence and mission archives. One problem with these sources is that the majority of them were written by non-Africans who harboured racist attitudes toward Africans. Even missionaries, who were staunchly against slavery and often came to the defense of African children, were imbued with a sense of European superiority and these attitudes need to be considered when analyzing these types of records. This requires them to be read both critically and cautiously.

As the prominent Africanist historian Frederick Cooper suggests, labelling Europeans as a symbol of imperial arrogance and evil has the same result as labelling them as a universal good; it makes the west the reference point when reading, and writing, African history. ${ }^{33}$ This research seeks, as much as possible, to view African childhood as constructed by Africans. While the colonial state and the laws and policies which it implemented were important, my work seeks to view the construction of African childhood as part of the history of Africa, rather than as an aspect of the history of Europeans in Africa.

The vast collection of photographs in the Basel Mission Archive has been invaluable to this research. While the voices of women and children are often absent

\footnotetext{
${ }^{32}$ Gwynn Campbell, Suzanne Miers and Joseph C. Miller, eds., Children in Slavery Through the Ages, I-II.

${ }^{33}$ Frederick Cooper, "Africa's Pasts and Africa's Historians," 302.
} 
from the written records, their images were captured and preserved by missionaries in the interior of the colony. These photographs offer insight into the work that was done by women and children at the mission stations, they suggest the types of clothing worn by children and the kind of food they were required to prepare. The photographs give an idea of the experience of girls at mission schools and who was responsible for their education. Many of the photographs are staged by the Basel Mission members who took the photographs and, of course, they must still be analyzed critically, but they offer a view of childhood at the mission station that simply cannot be extracted from written sources.

The experiences of children, narrated from their own perspective, do not appear explicitly in any colonial era sources. Thus, missionary records, newspaper articles and British correspondence records need to be read "against the grain" in an attempt to separate the voices of children from the voices of the authors, who are always adults, and often European. As Trevor Getz suggests, this is not an impossible task. These sources offer historians a mode of entry and a method of locating the voices of "common peoples" that are otherwise inaccessible because of the low level of literacy in colonial West Africa. ${ }^{34}$ Getz emphasizes the importance of court records as sources through which historians can understand the ways in which history has been contested. This way of reading primary sources, whether they are missionary or official British government

\footnotetext{
${ }^{34}$ Trevor R. Getz and Liz Clarke, Abina and the Important Men: A Graphic History (New York: Oxford University Press, 2012). xv.
} 
correspondence aids in understanding the ways in which childhood was negotiated and contested in colonial Ghana.

One way in which to do this is to look at the actions of children and what they might tell us about how and when glimpses of their existence surface in these documents. For example, the motives and experiences of children can be understood by looking at traces of their actions. Cases in which children ran away from their masters, or from mission stations and schools, can be particularly helpful. Instances in which children rebelled, attempted to protect each other, or sought protection from missionaries or colonial officials can also offer insight.

One of the least effective methods of reading history is as a story of progress. Using progress as a gauge privileges the west and evaluates the rest of the world according to what they are perceived to be lacking - materially, socially and intellectually. ${ }^{35}$ It assumes that Europeans have set the standard, as the dominant force in shaping the African continent and that Africa has failed to "progress" as far as the west due to African inferiority. It is this particular reading of history that complicates the contemporary issue of child labour and suggests why a more nuanced historical study of child labour in colonial Ghana is not just important but necessary.

\footnotetext{
${ }^{35}$ Cooper, "Africa's Pasts and Africa's Historians," 318.
} 


\section{Historical Context: Early Colonial Ghana}

By the sixteenth century, the Twi speaking Akan people had become the dominant political group in the region that would later become the Gold Coast Colony and Protectorate. Akan society was organized into states, families and brotherhoods. The extended family was an important institution in Akan communities that had been developed as a method of organizing shared labour, particularly large scale work like clearing forests and planting crops. ${ }^{36}$ These groups were organized primarily along matrilineal lines; however, people were often brought into the group from outside. This was particularly common in the case of the assimilation of slaves into the family group. This aspect of domestic slavery, or dependency, was confusing to European missionaries and colonial officials and contributed, in part, to the debate over the extent to which slavery continued to exist in the colony following British annexation of the region centuries later. ${ }^{37}$ It will be discussed in more detail in Chapter Two that the Basel Mission Society was heavily involved in this debate and even contemplated the purchase of slave children whom they imagined would live at the mission station as "refugees".

Akan society became much more complicated following the sixteenth century. The rise of Asante supremacy, the presence of European traders on the coast and the emergence of palm oil as an important, and sought after, resource led to significant changes in the region. ${ }^{38}$ Initially, local rulers were able to play these European traders

\footnotetext{
${ }^{36}$ Getz and Clarke, Abina and the Important Men, 99-100.

${ }^{37}$ Getz and Clarke, Abina and the Important Men, 99-100.

${ }^{38}$ Portuguese merchants were present on the coast as early as the $1470 \mathrm{~s}$. They were followed later by Dutch traders in the 1590s. Soon after this, the British, French, Dutch, Swedish and German merchants were all present in the coastal region at one time. (Getz and Clarke, Abina and the Important Men. 103).
} 
against each other which resulted in no one European power being able to secure a real foothold in the region. This changed as Britain began to reap the benefits of rapid industrialization at home. They were able to exert significant commercial and military power on the African coast and successfully expelled competing European powers by early $1870 s^{39}$

In an effort to further fuel this industrialization, the British needed to acquire increasing amounts of palm oil (which was used as a machine lubricant as well as in the production of soap). This led to an increased investment in controlling the region and the growth of their power on the coast put the British in direct competition with the Asante controlled interior. ${ }^{40}$ The Asante were prevented from continuing to export slaves due to British coastal control that resulted, essentially, in a blockade of Asante's principal export and greatest source of foreign income. In the mid-nineteenth century, however, some of the coastal African rulers aligned with the British against Asante and, the British formally annexed the region in 1874, following the last British-Asante War (1873-1874). ${ }^{41}$ Despite their military victory and official annexation, colonial authorities actually had limited control in the region and, thus, collaboration with African communities was necessary in order to govern. ${ }^{42}$ In the interior, the Basel Mission faced the same

\footnotetext{
${ }^{39}$ Getz and Clarke, Abina and the Important Men, 103.

${ }^{40} \mathrm{Getz}$ and Clarke, Abina and the Important Men, 103.

${ }^{41}$ John Carmichael, African Eldorado: Ghana from Gold Coast to Independence (London: Gerald Duckworth and Co. Ltd., 1993), 126.

${ }^{42}$ The 1873-1874 British-Asante War was a "turning point" in the history of the region. The British defeat over the Asante was much more complete than in previous conflicts since the mid-nineteenth century. The British were able to establish a broad protectorate region and as a result could institute anti-slavery policy that abolished the legal status of slavery. (Paul Lovejoy, "Introduction." In Slaves and Slaveholders on the Gold Coast: Towards an Understanding of Social Bondage in West Africa, edited by Peter Haenger (Basel, Switzerland: Schlettwein, 2000), x.
} 
challenges as colonial officials. In order to establish mission stations and encourage local Africans to send their children to mission schools, members of the Basel Mission also needed to negotiate with African community leaders and parents of local children. ${ }^{43}$

Following their victory, the British were able to create a series of agreements with local rulers that resulted in the creation of the Gold Coast Colony and Protectorate. The "Colony" was the area in which it was generally accepted that the British had established formal rule. Towns like Cape Coast and Christiansborg, which could be controlled by the presence of large forts, were considered to lie within the "Colony." The "Protectorate" referred to the majority of the Gold Coast region and included the small states that had been British allies during the war as well as those which had been allied with the Asante. These "Protectorate" states were, in many ways, independent, but they did have to agree to some rules that were imposed by the British, for example, the abolition of slavery for which there was intense pressure from evangelical and humanitarian groups in Britain. ${ }^{44}$

The ending of the slave trade had contributed to an economic decline (for both African and European traders) in the region and some historians attribute the outbreak of the Asante War to this decline. For more than two centuries, the salve trade had been the dominant influence on the region and had provided employment for thousands of people. Additionally, social structures had emerged during this period that led to a neglect and decline of traditional agricultural development and trade. As a result, it was imperative that new sources of income be developed and alternative commodities (rice, timber,

${ }^{43}$ Getz and Clarke, Abina and the Important Men, 99-100.

${ }^{44}$ Getz and Clarke, Abina and the Important Men, 103. 
maize, indigo etc.) were not as lucrative as the slave trade had been. ${ }^{45}$ As the Atlantic slave trade declined, however, there was a shift toward "legitimate trade" through the rise of cash crop agriculture, palm oil in particular, and later cocoa. ${ }^{46}$

In 1874, when the British secured political control the region, the administrative system was extended through a network of district officers. This system was much less centralized than it was in French Africa and while the British Colonial Office did exercise some control, their philosophy was very much laissez-faire. ${ }^{47}$ Individual colonies within the British Empire were given considerable autonomy locally and while the over-all policy was directed from London, most administrative decisions were made within the colony. While the British government wanted to maintain control, it also preferred that the colonial directors demonstrate some ability to adapt to local systems of governance that were already in existence. ${ }^{48}$

One consequence of this type of rule, which will be discussed in more detail in Chapter One and Chapter Two, was the need for British colonial officials, as well as missionaries, particularly in cities like Cape Coast and Christiansborg, but also in the interior of the colony, to work with African rulers and elites in order to expand their influence and to institute British policy. The ability of the British to maintain control in the region was, in many ways, dependent upon their relationship with African leaders and

\footnotetext{
${ }^{45}$ Carmichael, 161.

${ }^{46}$ Ulrike Sill, Encounters in Quest of Christian Womanhood: The Basel Mission in Pre-and Early Colonial Ghana (Boston: Brill and Leiden, 2010). 97.

${ }^{47}$ Carmichael, 180.

${ }^{48}$ Carmichael, 180.
} 
it was within this context that childhood became something of a battleground morally, legally and ideologically.

\section{Organizing Principles}

This thesis explores children, childhood, and the coerced labour of children in nineteenth century Ghana. It is broken down into two key themes: The effect of the Emancipation Ordinance and the Master and Servant Ordinance on the condition of African children, and the experience of children who attended Basel Mission schools or lived at the mission stations. Taken together, these two sections argue that the colonial government and European missionaries were implicated in the creation of policies and practices that allowed for the enslavement of children and ran counter to the ideological tenets of evangelicals and humanitarians.

Chapter One discusses the abolition of slavery in the British Empire and in colonial Ghana in particular. It deals specifically with two important pieces of legislation enacted in 1874 and 1876 respectively: the Emancipation Ordinance and the Master and Servant Ordinance. Within this context, the effects of this legislation on the lives of African children will be analyzed. Some examples of court cases in which children contested their position as slaves will be used to further examine the extent to which the legal system was able to help in granting the freedom of child slaves and how effectively the colonial government was able to transition the victims into colonial society and the wage labour economy. 
Chapter Two deals with children and the Basel Mission in colonial Ghana. Using the Basel Mission records, Chapter Two will explore the experience of children who were part of the Protestant congregations of the Basel Mission in the interior of the colony. It deals with the gendered construction of childhood and the different experience of girls and boys at mission schools and explores the ways in which children managed to take control of their own labour and attempted to negotiate its terms. Additionally, this chapter looks at the priorities of the Basel Mission vis-à-vis the abolition of slavery and the slave trade and their interaction with African children. 


\section{Chapter One - Children, Childhood, and Emancipation Legislation in Colonial Ghana}

The expansion of the European controlled Atlantic slave trade had a significant impact on domestic slavery in West Africa. As the Atlantic slave trade grew, slaves became more prominent in local African societies and slavery underwent a transformation from being a "marginal feature" to an "important institution" within Africa. ${ }^{49}$ By the same token, as the Atlantic slave trade and slavery more broadly, became illegal throughout the British Empire, African societies were also significantly affected. Full scale abolition was a European concept that was "born out of the conflicts in the eighteenth century by the expansion of capitalism and the profound ideological changes which accompanied it." ${ }^{50}$ In Britain during the late-eighteenth and early-nineteenth centuries, slavery began to be seen as being essentially opposed to humanitarian and Christian religious ideals as well as incompatible with the needs of the emerging capitalist economy. The British emancipation experience in the Caribbean and in India shaped the steps that were taken when slavery was later outlawed in colonial Ghana. Despite deep anti-slavery sentiments in Britain, and in many parts of the Empire, the Emancipation Ordinance in Ghana did not abolish the institution of slavery, and thus, the forced labour of children continued.

European colonial powers used the notion that they had a duty to civilize 'slaves, sinners and savages' as a justification for colonialism. Missionaries, British officials and

\footnotetext{
${ }^{49}$ Paul Lovejoy, Transformations in Slavery: A History of Slavery in Africa (Cambridge; New York: Cambridge University Press, 1983), 18.

${ }^{50}$ Suzanne Miers \& Richard Roberts. "Introduction: The End of Slavery." In The End of Slavery in Africa, edited by Suzanne Miers and Richard Roberts (Madison WI: University of Wisconsin Press, 1988), 8.
} 
administrators, and colonial courts all played a central role in both the regulation of antislavery laws and the continuation of slavery-like conditions, particularly among African children. ${ }^{51}$ Following the abolition of slavery, a number of cases in which people were accused of buying, selling, or owning slaves were heard before the colonial courts. The fact that these cases were heard at all, regardless of their outcome, suggests that an increasing number of Africans, including slaves themselves, were making use of the judiciary system because it "represented an alternative to local forms of justice particularly with regard to questions of previous conditions of dependency." 52

This chapter examines the effects of the Emancipation Ordinance and the Master and Servant Ordinance on the lives of enslaved children in colonial Ghana. It argues that despite this legislation and the ideological abhorrence of the institution of slavery, the condition of slave children was not significantly improved even when they were able to plead their case in the colonial courts. There are three main reasons that this was the case. Firstly, colonial officials in Ghana believed that African slavery was "benign" when compared to the chattel slavery of the Caribbean and as a result they did not approach abolition with any discernable degree of urgency. Second, the colonial courts failed to effectively deal with child victims after their masters had been convicted. In many cases those found guilty of slave trading or slave holding rarely faced more than a small fine and, in many cases, the children they were accused of holding as slaves ended up back in their care. Third, the lack of real control outside the coastal areas of the colony made it difficult for officials to prevent the trafficking of children from outside the

${ }^{51}$ Michael N. Barnett, Empire of Humanity (Ithica, NY: Cornell University Press, 1022), Chapter 3, 57-75. ${ }^{52}$ Peter Haenger, Slaves and Slaveholders, 149. 
protectorate where they were subsequently sold as slaves in coastal areas like

Christiansborg (Accra) and Cape Coast.

\section{Freeing Slaves without Abolition}

During the early nineteenth century, significant changes in West African exports

occurred. This was a result of a re-orientation of the economy of the region as the focus shifted from the export of slaves to the export of agricultural products like palm oil, palm kernels, and other 'legitimate trade' items. ${ }^{53}$ This shift in production resulted in the increased use of slaves in the local economy and slaves became the largest component of the labour force in West Africa. ${ }^{54}$ Thus, as Lovejoy argues, slavery became more of a social institution than it had previously been. Similarly, pawnship became increasingly common because of significant changes in agricultural practices in the region. By the 1890s, the people of Akwapim, for example, had begun to produce cocoa, which required less labour and yielded higher profits than palm oil. "Wealth-in-people" was part of a much more broad commercial and economic system in which both men and women participated as "dependents, and as slave-owners, pawn-holders and as patrons."56 The role of children in this system was as slaves as pawns. ${ }^{57}$

\footnotetext{
${ }^{53}$ Lovejoy, Transformations in Slavery. 159.

${ }^{54}$ Lovejoy, Transformations in Slavery. 160.

${ }^{55}$ Catie Coe, "How Debt Became Care: Child Pawning and Its Transformations in Akuapem, the Gold Coast, 1874-1929." Africa 82, 2 (2012): 287-311. 290.

${ }^{56}$ Ulrike Sill, Encounters in Quest of Christian Womanhood. 105

${ }^{57}$ Lovejoy, Transformations in Slavery. 160. Participation in the transatlantic slave trade had domestic repercussions in West Africa. First, slavery grew as an institution. The ending of the transatlantic slave trade and the increased demand for West African agricultural products created an increased demand for labour in the region. Second, domestic slavery and debt bondage were conceptualized. They began to be conceived of as commercial arrangements rather than lineage-based intuitions. Originally, pawning, or
} 
Trevor Getz and Catie Coe both argue that while pawnship existed in tandem with the Atlantic slave trade and that the system of pawnship and that of the Atlantic slave trade were very much separate, they did have some effect on each other. For example, Getz suggests that the existence of the Atlantic slave trade transformed domestic slavery and pawnship in that the labour of dependents was re-organized in order to provide food for slave caravans as well as to provide resources for new slave-trade based towns. ${ }^{58}$ Getz also argues that during the Atlantic slave trade, pawnship transitioned to a predominantly commercial transaction in which pawns could end up much farther away from their family or kin group. ${ }^{59}$ The majority of slaves who were sold into the Atlantic slave trade were men and, thus, domestic slavery became dominated by women and children. ${ }^{60}$ Toyin Falola and Paul Lovejoy suggest that while we cannot be certain about the demographics of pawns in West Africa, it is likely that most were children and youth because of their subordinate position within the family. ${ }^{61}$

Until the mid-eighteenth century, there was little objection to slavery in Britain. By the late-eighteenth century, however, it was increasingly denounced on moral and rational terms as well as by merchants and manufacturers who had accumulated wealth

debt bondage, was used as a means through which to acquire labour temporary labour. By the nineteenth century, increased interest rates on the initial debt began to transform pawnship into a much more permanent institution. Children were greatly affected by these changes as they could potentially spend their entire lives in bondage rather than a portion of their early life. (Trevor R. Getz, "British Magistrates and Unfree Children in Early Colonial Gold Coast." In Child Slaves in the Modern World, Edited by Gwynn Campbell, Suzanne Miers and Joseph C. Miller. (Athens, OH: Ohio University Press, 2011) 157172. 158-159.)

${ }^{58}$ Trevor R. Getz. Slavery and Reform in West Africa: Toward Emancipation in Nineteenth-Century Senegal and the Gold Coast. Western African Studies (Athens, OH: Ohio University Press, 2004). 181.

${ }^{59}$ Getz. Slavery and Reform, 23.

${ }^{60}$ Getz and Clarke, Abina and the Important Men: A Graphic History, 108.

${ }^{61}$ Toyin Falola and Paul E. Lovejoy, "Pawnship in Historical Perspective." In Pawnship in Africa: Debt Bondage in Historical Perspective, edited by Paul E. Lovejoy and Toyin Falola, (Boulder, CO: Westview Press, 1994). 13-14. 
and power that was not related to slavery or the slave trade. As a result, the political power of Caribbean planters had begun to decline considerably. ${ }^{62}$ In 1833 , Britain abolished slavery in its Caribbean colonies. To ease the transition, slave-owners were compensated for the loss of their slaves and ex-slaves remained on their masters' land as apprentices for a period. Significant efforts were made in order to maintain the land rights of former owners and to prevent former slaves from negotiating the terms of their labour. Despite the steps taken by the British, freed slaves were able to avoid entering the labour market by becoming artisans, small land holders and subsistence farmers and in most cases, former female and child slaves withdrew from the workforce altogether. ${ }^{63}$ As a result, production declined and former slave holders turned to other methods of exploitation, in particular indentured servants from India and China. ${ }^{64}$ The abolition of slavery was not intended to completely dismantle the social hierarchy of the Caribbean plantation system. Prior to abolition, the plantation system had been the instrument through which labour was organized in the Caribbean colonies. Thus, when former slaves took control of their labour, officials and abolitionists alike were unprepared for the post-emancipation labour crisis. ${ }^{65}$

Interestingly, the 1833 legislation that ended slavery in the British Caribbean did not deal at all with the practice of slavery in India. Slavery continued to exist in India and in other British colonies and dependencies. ${ }^{66}$ Colonial officials in India resisted implementing anti-slavery policy until the British government, acting under intense

\footnotetext{
${ }^{62}$ Suzanne Miers, Britain and the Ending of the Slave Trade (New York: Africana Pub. Corp, 1975). 3-5.

${ }^{63}$ Miers and Roberts, "The End of Slavery in Africa." 10.

${ }^{64}$ Miers and Roberts, "The End of Slavery in Africa." 10.

${ }^{65}$ Miers and Roberts, "The End of Slavery in Africa." 10.

${ }^{66}$ Suzanne Miers, Ending of the Slave Trade, 31.
} 
pressure from humanitarian groups, forced the colony to do so in 1843. Slave trading was forbidden in the colony and slavery was "declared to have no legal status in British India". ${ }^{67}$ Generally, slaves in India were not informed that they were effectively free and they were certainly not encouraged to leave their masters' land. However, if they did leave on their own, they could not be forced to return through any legal action the part of former owners. The result was a long period of transition during which slaves gradually became aware of their new status. ${ }^{68}$ Unlike in the British Caribbean which had a predominantly white slave-holding class, no compensation was paid to Indian slave holders. Colonial officials assumed that slavery would gradually die out and it was not until 1862, seventeen years later, that it actually became a crime to own slaves in colonial India. ${ }^{69}$ The Indian model for abolition was intended to end slavery gradually without jeopardizing social order or threatening the colonial economy.

A Similar strategy was used in British West Africa. Upon the receipt of a letter from the Earl of Carnarvon, the governor of the Gold Coast recommended that a scheme to abolish slavery be implemented in colonial Ghana. It was stipulated that this plan should very closely mimic the scheme which had been employed in India. During the annexation process in 1874, the Earl of Carnarvon wrote to Gold Coast Governor George Cumine Strahan (June 1874 - April 1876) regarding his concerns about slavery. He stated. "there remains the question of the existence of slavery within the range of the Queen's influence and authority. It is one surrounded by many serious difficulties, but it

\footnotetext{
${ }^{67}$ Miers and Roberts, "The End of Slavery in Africa," 12.

${ }^{68}$ Miers, Ending of the Slave Trade, 157.

${ }^{69}$ Miers and Roberts, "The End of Slavery," 12.
} 
is also one which affects, by its existence, not only the honour and traditional policy of this country, but the welfare and good government of the Gold Coast." ${ }^{70}$

In September 1874, Governor Strahan wrote back to the Earl of Carnarvon recommending a proposal that called for "the immediate and absolute prohibition of slave-dealing in every form including the prohibition of the importation of slaves and persons to be sold as slaves, and a declaration of the unconditional freedom of such persons." ${ }^{, 71}$ Also included in Strahan's proposal was a stipulation that all children born after a date to be determined later, would be declared free. As for the freedom of the existing slave population, no formal declaration would be made, but in his letter Strahan identified that "they would substantially and for practical purposes be equally free as these children [those freed upon birth].,72

Using a variation of the model employed in India, the legal status of slavery was eliminated in colonial Ghana in 1874. Slavery, slave-dealing and pawnship were made illegal and any contracts related to slavery were declared void. ${ }^{73}$ However, colonial officials often returned fugitive slaves to their masters in the protectorate, where British law was rarely enforced unilaterally. ${ }^{74}$ The laws banning slavery made it possible for the enslaved to seek their own freedom, but did not actually require colonial officials to root

\footnotetext{
${ }^{70}$ British Parliamentary Papers, February 6, 1875 C-1139, C-1140, "Correspondence Relating to the Queens's Jurisdiction on the Gold Coast and the Abolition of Slavery Within the Protectorate."

${ }^{71}$ British Parliamentary Papers, February 6, 1875, C-1139, C-1140.

${ }^{72}$ British Parliamentary Papers, February 6, 1875, C-1139, C-1140.

${ }^{73}$ Miers, Ending of the Slave Trade, 158.

${ }^{74}$ Lovejoy, Transformations in Slavery, 247.
} 
out instances of slavery or to punish those involved in slave holding or slave dealing.

Essentially, the responsibility was placed on the enslaved to liberate themselves. ${ }^{75}$

The development of colonial policy regarding slavery needed to appease abolitionists at home and also prevent the kind of mass slave liberation that occurred in the British Caribbean. Two laws, which were both reflective of the Indian emancipation experience, were implemented in $1874 .^{76}$ The Anti-Slave Trade Ordinance called for a ban on the importation of slaves into the colony and the Emancipation Ordinance required that slaves who wanted to liberate themselves officially apply to a British official in order to gain their freedom. ${ }^{77}$ The Emancipation Ordinance "stated that slaveholding was illegal," but colonial officials were not permitted to interfere in masterslave relations that predated this policy. ${ }^{78}$ Exceptions to this were in cases in which a slave appealed to a magistrate or District Commissioner and if a slave accused his or her master of "forcible constraint or cruelty."79

Getz suggests that, while the Emancipation Ordinance and the Anti-Slave Trade Ordinance were intended to show that colonial administrators were ideologically committed to the liberation of slaves in the colony, the manner in which it was enforced actually suggests their acceptance of the traditional master-slave relationship. The colonial government did not overtly advocate that slaves seek liberation from their masters and, in Getz's view, the administration essentially provided a route for

\footnotetext{
${ }^{75}$ Getz and Clarke, Abina and the Important Men, 108.

${ }^{76}$ Getz, "British Magistrates and Unfree Children," 162.

77 Getz, "British Magistrates and Unfree Children," 162.

${ }^{78}$ Dumett and Johnson, "Britain and the Suppression of Slavery." In The End of Slavery in Africa, edited by Suzanne Miers and Richard Roberts (Madison WI: University of Wisconsin Press, 1988). 85.

${ }^{79}$ Dumett and Johnson, "Britain and the Suppression of Slavery," 85.
} 
emancipation without drastically altering the economic, political or social landscape. In this way, abolition in colonial Ghana was similar to the manner in which slavery was phased out in India. ${ }^{80}$ This strategy was not acceptable in the eyes of Britain's humanitarian organizations and evangelical philantropists and they began to lobby the Colonial Office in an effort to improve the manner in which anti-slavery laws were administered in the colony.

This approach to anti-slavery policy made children the primary victims of the continued importation of slaves from the north. "Children were not specifically discussed by the architects of the antislavery acts because it was presumed, correctly, that the young would be highly unlikely to liberate themselves." ${ }^{81}$ Thus, access to labour was not affected by new anti-slavery legislation and slave traders began to prefer children, especially those who had been smuggled into the colony and children from the north. ${ }^{82}$ This increased use of children as forced labourers and slaves ensured "the stability and profitability" of the colony because children were much less likely than adults to challenge their status. ${ }^{83}$

\footnotetext{
${ }^{80}$ Getz, Slavery and Reform, 102-104.

${ }^{81}$ Getz, "British Magistrates and Unfree Children," 163.

${ }^{82}$ Getz, "British Magistrates and Unfree Children," 163.

${ }^{83}$ Getz, "British Magistrates and Unfree Children," 169.
} 


\section{Consequences of the Emancipation Ordinance for African Children}

\section{The Aborigines Protection Society}

Following the Emancipation Act in 1833, evangelical philanthropic groups began to take an interest in the "protection" of Indigenous peoples in British colonies and dominions. ${ }^{84}$ The Aborigines Protection Society was founded in 1837 as a result of a House of Commons Committee appointed in 1835 "to consider what measures ought to be adopted with regard to the native inhabitants of countries where British settlements are made and to neighbouring tribes in order to secure them justice and the protection of their rights." The organization was active as a pressure group in all areas of the empire including, Canada, Australia, South Pacific Islands, and Africa. Initially their involvement in Africa was limited to South Africa, but it eventually extended to West Africa as well. ${ }^{85}$ In addition to their desire to "protect" indigenous peoples, the Aborigines Protection Society also desired to "promote the spread of civilization among them, and to lead them to the peaceful and voluntary reception of the Christian religion." ${ }^{, 86}$

By the early 1890s, the Aborigines Protection Society had a world-wide reputation for launching humanitarian campaigns and trying to apply pressure to governments in the metropole as well as in the colonies. Henry Richard Fox Bourne, the Secretary of the Aborigines Protection Society, encouraged residents in urban areas of colonial Ghana to organize "local communities so as to supply beneficial information to

\footnotetext{
${ }^{84}$ Kenneth D. Nworah, “The Aborigines' Protection Society, 1889-1910: A Pressure-Group in Colonial Policy," Canadian Journal of African Studies 5, 1 (1971): 79-91. 79.

${ }^{85}$ Anti-slavery and Aborigines Protection Society (Great Britain), Anti-Slavery International, and Adam Matthew Digital (Firm), The Anti-Slavery and Aborigines Protection Society Being the Amalgamation, Effected on 1st July 1909, of the British and Foreign Anti-Slavery Society and the Aborigines Protection Society (London: Anti-slavery and Aborigines Protection Society, 1909).

${ }^{86}$ Nworah, "The Aborigines Protection Society," 79.
} 
his Society. ${ }^{187}$ As a result of appeals made to the Colonial Office regarding the continued existence of slavery in colonial Ghana, the Society was able to have thirty-six Africans released from jail following a trial, the proceedings of which they viewed as being questionable. ${ }^{88}$ The Society persistently advocated against the enslavement of children and Kenneth Nworah argues that they may have been a factor in gradual improvements in the enforcement of anti-slavery legislation in the colony. While they did advocate aggressively for change to the administration of the law, they also maintained a policy of not releasing the names of their local informants and members even when the government requested the information. This caused the Colonial Office to accuse the organization of fabricating some of their reports and complaints. ${ }^{89}$

Following the Emancipation Ordinance, the use of women and children, girls in particular, as slaves continued to be particularly common. Getz argues that women and children were perceived by slaveholders to be less likely to run away or to report their condition to British officials. ${ }^{90}$ Children, in particular, were easily hidden from colonial officials or passed off as their own children by slave traders. Additionally, children learned new languages much more easily than adults and it was relatively simple to disguise where they were from. Child pawns could also be easily hidden from officials or disguised as fosters. ${ }^{91}$ In 1890 , the Aborigines Protection Society in Colonial Ghana suggested that since the passing of the Emancipation Ordinance, adult slavery had been largely suppressed, but that in their estimation approximately five thousand children

\footnotetext{
${ }^{87}$ Nworah, "The Aborigines' Protection Society," 83.

${ }^{88}$ Nworah, "The Aborigines' Protection Society," 83.

${ }^{89}$ Nworah, "The Aborigines' Protection Society," 83.

${ }^{90} \mathrm{Getz}$ and Clark, Abina and the Important Men. 108.

${ }^{91}$ Coe, "How Debt Became Care," 299.
} 
(both boys and girls) were still living as slaves. ${ }^{92}$ In their estimation, the majority of these children had been brought from the interior as well as from areas outside the protectorate for sale in Accra and other coastal towns. ${ }^{93}$ The colonial administration acknowledged that this exploitation of children existed in the Gold Coast Colony and Protectorate, but they did not actively attempt to eradicate slavery or slave dealing. Some administrators noticed that there was an increase in imported children in the colony, but they usually adhered to the intent of the anti-slavery laws and did not pursue the issue unless they were forced to do so. According to Getz, colonial administrators felt that an aggressive approach to the increase in the importation of slave children would "create a class of vagabonds" which would constitute a threat to colonial social order. ${ }^{94}$

In 1888, Governor Griffith instructed District Commissioners to post notices throughout the colony to educate people regarding abolition laws. In 1890 District Commissioners were ordered to "vigorously enforce the abolition laws, paying particular attention to 'apprenticed children." 95 Despite this, slaves appear to have been relatively unaware of their rights. Kwanbena Opare-Akurang suggests that abolition legislation was only really administered when there was pressure from both anti-slavery groups in Britain and from the Colonial Office. ${ }^{96}$ Since the colonial government did not take an active role in the suppression of slavery in the region, slaves were forced to take the initiative themselves. In order to seek the freedom they were legally entitled to, slaves

\footnotetext{
${ }^{92}$ British Parliamentary Papers, May 1891, C-6354.

${ }^{93}$ British Parliamentary Papers, May 1891, C-6354.

${ }^{94}$ Getz, "British Magistrates and Unfree Children," 164.

${ }^{95}$ Kwanbena Opare-Akurang, "The Administration of the Abolition Laws, African Responses, and PostProclamation Slavery in the Gold Coast, 1874-1940," Slavery and Abolition: A Journal of Slave and PostSlave Studies 19, (1998): 149-166. 152.

${ }^{96}$ Opare-Akurang, "The Administration of the Abolition Laws," 150.
} 
needed to run away from their masters and find refuge in areas of the colony that were completely unfamiliar to them. Once they reached a city like Cape Coast, they needed to have their case heard in a colonial court. Trevor Getz suggests that the fact that any enslaved children and youth were able to do this is really quite amazing. ${ }^{97}$

Getz and Liz Clarke reconstruct one such experience in their book Abina and the Important Men: A Graphic History. Abina Mansah was a young woman who was kidnapped in Asante territory in the interior of the colony and enslaved at two different households in that region before being sold to a slave trader. This trader took her to a town called Salt Pond, near Cape Coast, and sold her to a man named Quamina Eddoo. Eddoo, in turn, gave Abina to his sister for whom Abina was required to work. Shortly after being given to Eddoo's sister, Abina was told to marry a man named Tandoe. At this point, she ran away from her mistress' house and arrived in Cape Coast where she convinced James Davis, a prosecutor, to help her plead her case in the colonial courts. ${ }^{98}$ Quamina Eddoo was found not guilty by the judge in 1876, but Abina's case is evidence of the lengths to which the enslaved had to go in order to achieve the freedom they had been officially granted with the enactment of the Emancipation Ordinance. There were children who did run away and plead their cases in front of colonial courts, but there were many more throughout the colony who did not have either the knowledge or the ability to flee and, thus, continued to live in slavery, or slavery-like conditions.

As Getz suggests, it is remarkable that some enslaved children and youth were able to run away and seek freedom, but even with the enactment of the Emancipation

${ }^{97}$ Getz and Clarke, Abina and the Important Men, 108.

${ }^{98} \mathrm{Getz}$ and Clarke, Abina and the Important Men, 109. 
Ordinance, it was the minority of enslaved peoples who were able to do this. The majority of enslaved women and children continued to reside with their masters. Even after the abolition of slavery, there were many reasons that buying slaves, particularly women and children, remained an attractive option to people in the colony. For example, a man who did not, or could not, marry could buy a slave with whom he could have children whom he would be able to control completely. ${ }^{99}$ Women, and couples without children, could buy slaves in order to have help in their older age, slave labour made it much easier for invalids to manage, and farmers could expand their labour force through the purchase of slaves. ${ }^{100}$ Peter Haenger suggests that slaves were fairly easy to come by and, child slaves especially, remained a regular fixture of life in most parts of the colony. ${ }^{101}$ British resources were stretched fairly very thin and a result the primary focus of the colonial government was the coastal, more urban, areas. Thus, in this way, the colonial government did play a role in facilitating slavery in the protectorate region. ${ }^{102}$ There were very few Europeans, missionaries being the only exception, in the interior of the colony and as a result it was nearly impossible to enforce the new anti-slavery laws beyond the coastal cities and towns. ${ }^{103}$ Many children and youth were enslaved in the protectorate, or smuggled through the region, because of the colonial government's inability to effectively enforce the law.

The colonial governor, William Brandford Griffith (December 1880 - March 1881), wrote in an 1891 letter that "these children... are free to leave these households

\footnotetext{
${ }^{99}$ Haenger, Slaves and Slaveholders, 155.

${ }^{100}$ Haenger, Slaves and Slaveholders, 155.

${ }^{101}$ Haenger, Slaves and Slaveholders, 155.

102 Opare-Akurang, "The Administration of the Abolition Laws," 154.

${ }^{103}$ Miers, Ending of the Slave Trade, 159.
} 
when ill-treated and go elsewhere if they choose to do so; their condition is far less binding than the system of apprenticeship recognized in England."104 He added that, "it has become extremely difficult to keep one's own household and amongst one's own children, and if you chastise your own child for any act of disobedience rendering necessary a slight castigation, the child will threaten to take you to court before the District Commissioner." "While this is technically correct, according to the law, it is somewhat unreasonable, as Trevor Getz has pointed out, to expect that the majority of enslaved children would really be able to leave their masters' households on their own. Given this apathetic, even callous, attitude toward the problem of slavery in the colony in the late-nineteenth century by those charged with enforcing the law, it is not surprising that the forced labour of children continued to exist in various forms even after it was declared illegal.

In response to Griffith's comments, the Aborigines Protection Society stated, "it may be taken for granted that adults understand and are able to assert their rights; but that children sold into bondage, often when they are only four or five years of age, are competent to protect themselves from those who claim to be their owners is an assumption inconsistent with reason and fact."106 This is even more pronounced when taking into account the number of children who were being held in slavery far from their homes with no family nearby. In these cases, even if the children were aware that theoretically they were legally able to leave their masters' homes, in reality they may not

\footnotetext{
${ }^{104}$ British Parliamentary Papers, May 1891, C-6354.

105 British Parliamentary Papers, May 1891, C-6354.

${ }^{106}$ British Parliamentary Papers, May 1891, C-6354.
} 
have even known where they had lived prior to their enslavement, or how to get there. Attempting to actually leave their masters' house and return to their homes would have been a completely overwhelming endeavour and likely would have required the help of an older child or an adult.

It was nearly impossible to administer the Emancipation Ordinance in the protectorate because of how far apart colonial officials were stationed; however, even in the coastal regions where there were more colonial officials and administrators, antislavery policy was inconsistently directed. Opare-Akurang suggests that this was, at least in part, a result of "poor communication between District Commissioners and the legal department" of the colonial government. ${ }^{107}$ This particular failure of the colonial government led to more children being brought into the colony as slaves. The Aborigines Protection Society complained to the Colonial Office when Governor Griffith stated that child slavery "is a good thing in the children's own interests" and that slave children who were brought from some areas outside the colony "must be immensely benefitted by the change."108 This statement from the governor implies that the Colonial Office was excusing, rationalizing, or even justifying the enslavement of children throughout the colony and the Aborigines Protection Society actively lobbied to change this.

\footnotetext{
${ }^{107}$ Opare-Akurang, "The Administration of the Abolition Laws," 154.

${ }^{108}$ British Parliamentary Papers, May 1891, C-6354.
} 


\section{The Master and Servant Ordinance: Slave Children and the Colonial Courts}

The Master and Servant Ordinance, enacted in 1876, was designed to control the employment and training of children and youth in the colony and to ease the transition from slave labour to a wage labour system. ${ }^{109}$ Presumably, British officials wanted to avoid the kind of labour shortages that occurred in the Caribbean following the full-scale abolition of slavery. The Master and Servant Ordinance stated that orphaned children whose masters had been convicted of slaveholding would be placed in the care of "trustworthy people" in a relationship that resembled the European system of apprenticeship. ${ }^{110}$

In practice, however, this legislation was as difficult to enforce as the Emancipation Ordinance. Many children and youth continued to labour in slave-like conditions while their "employers" portrayed the relationships as those of employeremployee in front of the colonial courts. ${ }^{111}$ This was complicated further by the fact that in many cases it was the relatives or guardians of the children who had arranged these "slave-like relationships." 112 Even in cases in which people were convicted of buying and holding slaves, the colonial authorities were often unable to find appropriate apprenticeships for the children. ${ }^{113}$ Another challenge faced by slave children was the fact that the condition of slavery was often difficult to prove. Sometimes witnesses of the

\footnotetext{
${ }^{109}$ Similar legislation was later enacted in the Niger Coast Protectorate in 1901. It was called the Master and Servant Proclamation and its purpose was to enable House heads to "procure children as apprentices." As in colonial Ghana, the intention was for this law to serve as a temporary solution to labour shortages during the transition from slave labour to wage labour. (Suzanne Miers, Britain and the Ending of the Slave Trade, 1975, 301-302).

${ }^{110}$ Haenger. Slaves and Slaveholders, 148.

${ }^{111}$ Haenger. Slaves and Slaveholders, 147.

${ }^{112}$ Haenger. Slaves and Slaveholders, 147.

${ }^{113}$ Haenger. Slaves and Slaveholders, 148.
} 
sale of a slave, or the forced labour of a child were not willing to come forward; people were not necessarily eager to accuse their friends, neighbours, and family and turn them over to the courts; and sometimes notable people, who had the ear of the courts and other officials, were able to sway court decisions in their favour. ${ }^{114}$

In the summer of 1890 , the Colonial Secretary issued instructions to all District Dommissioners requesting that at the end of every quarter that each of them send a "list of the names and sex of all children apprenticed in [their] district, and the names of the persons to whom they are apprenticed." 115 These instructions also required that a certificate be included with the list of names. This certificate was supposed to act as assurance that the government was satisfied "that the apprentices have been well treated" under the care of their new guardians and that the law had been strictly observed during the placement process. ${ }^{116}$ While this policy may have been articulated to the District Commissioners in charge of the apprenticeship of former slave children, in practice antislavery legislation was much less effective.

One example of the utter ineffectiveness of the Master and Servant Ordinance is the 1890 case of Fanny Hagan. In March of 1890, Fanny Hagan, was prosecuted in Accra before the District Commissioner, Edward McMunn, and charged with slave dealing. The court determined that Ms. Hagan had, in fact, purchased a young girl named Nyamie Domah for the price of three pounds sterling. ${ }^{117}$ Following her conviction, Ms. Hagan was fined five pounds sterling and the child was placed in the care of the prison

\footnotetext{
${ }^{114}$ Opare-Akurang, "The Administration of the Abolition Laws," 159.

${ }^{115}$ British Parliamentary Papers, May 1891, C-6354.

${ }^{116}$ British Parliamentary Papers, May 1891, C-6354.

${ }^{117}$ British Parliamentary Papers, May 1891, C-6354 "Gold Coast Correspondence Respecting the Administration of the Laws Against Slavery in the Gold Coast Colony".
} 
matron. In keeping with the policy outlined in the Master and Servant Ordinance, Nyamie should have been apprenticed to a "trustworthy" citizen following her mistress' conviction. However, on the order of the colonial governor W. B. Griffith, Nyamie was returned to Fanny Hagan despite her being convicted of holding the girl as a slave. The District Commissioner stated that Ms. Hagan "is a respectable woman, and had I been selecting a mistress for a girl apprentice I would have given Fanny Hagan a favourable consideration." 118

According to Griffith, Fanny Hagan had written to the colonial secretary on the $27^{\text {th }}$ of March, 1890 and stated that she had been fined following a conviction for slave dealing. In her letter, she asked that "as the child on account of which she had been fined had been well treated, had cried in court to be allowed to return to her, and was a playmate of her own daughter, she might be apprenticed to her." ${ }^{\prime 19}$ Edward McMunn agreed that, "the child seemed perfectly happy and looked well fed and expressed considerable grief at being parted with the accused." ${ }^{\prime 20}$ McMunn did acknowledge that putting Nyamie in the custody of her former slave owner "might establish a dangerous precedent," but he also stated that, "the slavery [in colonial Ghana] is not (except in some isolated cases) injurious to the slaves, who are nearly always children of tender years."

The fact that the authorities involved in Nyamie Domah's case recognized that giving the child back to Fanny Hagan could complicate future cases involving slave dealing was off-set by the fact that they also justified their decision based on their

\footnotetext{
118 British Parliamentary Papers, May 1891, C-6354.

${ }^{119}$ British Parliamentary Papers, May 1891, C-6354.

${ }^{120}$ British Parliamentary Papers, May 1891, C-6354.

${ }^{121}$ British Parliamentary Papers, May 1891, C-6354.
} 
assessment of slavery in the colony as being "benign" when compared to the system of chattel slavery that had existed in the British Caribbean. District Commissioner L.M. Peregrine also rationalized Ms. Hagan's purchase of Nyamie by suggesting that Fanny Hagan did not know that Nyamie Domah was a slave. He claimed that Ms. Hagan had "asked a friend to procure a small girl for her to assist in carrying on her business." $\mathrm{He}$ argued that she could not have known that Nyamie was a slave girl because of her status as a "respectable woman" and because Nyamie had been represented to her "as a maidservant". ${ }^{122}$ This case illustrates the complicated nature of child labour in colonial Ghana particularly well. It highlights the inability of the colonial courts and administrators to properly make assessments regarding cases of slavery and to then act in the interest of the victims, the majority of whom were children. Opare-Akurang suggests that this was a serious failure of the colonial courts. They were almost entirely unable to establish a coherent system of policies and procedures that would have aided in the integration of freed slaves into society and improve the over-all transition from slavelabour to free labour in the colony. For years, the courts simply returned children to their masters who had been convicted of slave-holding which only served to perpetuate and further encourage slavery in colonial Ghana. ${ }^{123}$

In a September 1891 letter to the Colonial Office, the Aborigines Protection Society suggested that if cases of slavery in colonial Ghana were pursued adequately and those convicted were fined appropriately, there would have been enough money to establish and maintain an industrial school to help transition victims of slavery into

\footnotetext{
${ }^{122}$ British Parliamentary Papers, May 1891, C-6354.

${ }^{123}$ Opare-Akurang, "The Administration of the Abolition Laws," 155.
} 
colonial society and to prepare them to participate in the wage labour economy. They argued that this scheme was completely feasible as a similar school existed in Sierra Leone at the time which was better equipped to handle and care for former slave children until they could be apprenticed. ${ }^{124}$

According to the Aborigines Protection Society, the case of Nyamie Domah was by no means an isolated incident. In August of 1890, the group wrote to the Colonial Office to highlight a number of cases in which the colonial courts and administrators had failed to act in the interest of upholding the Emancipation Ordinance and the Master and Servant Ordinance. ${ }^{125}$ For example, in June 1890, under District Commissioner Peregrine, some slave boys had applied for liberation and they were told by Mr. Peregrine "that he was not set there (in the court) to decide any case of slave dealing" and he ordered that the boys must go back to their masters. ${ }^{126}$ In a similar case, in April 1890, a woman named Momoh was fined five pounds sterling for being in possession of a child slave named Cho Cho. Upon Momoh's conviction, the child was placed in the care of the chief warder of the prison until she could be apprenticed. On July $26^{\text {th }}$, Cho Cho was "enticed away [from the prison] by Momoh" and the child remained with her. ${ }^{127}$

There were also incidents in which charges were dismissed because of a lack of evidence. In 1887, a charge of slave dealing was brought against Ellen Quartey, a

\footnotetext{
${ }^{124}$ British Parliamentary Papers, May 1891, C-6354.

${ }^{125}$ British Parliamentary Papers, May 1891, C-6354.

${ }^{126}$ British Parliamentary Papers, May 1891, C-6354.

${ }^{127}$ British Parliamentary Papers, May 1891, C-6354.
} 
concubine of a white resident of Accra. ${ }^{128}$ According to the victim, a boy named Sam, he had been "sent by my mistress to buy something. On my way through town, I met a woman who declared she was my mother, she took me inside her house and asked me where I was staying. I told her I was staying with a certain lady in the town, she told me I must not go there again, she will bring me to the court to obtain my freedom."129 Ellen Quartey was charged with forcibly detaining the boy, who was found by his mother after having been enslaved for four years. The case was adjourned while more evidence was gathered and Ellen Quartey was released on her own recognizances. Sam told the court that he was not bought by Ms. Quartey, but in fact by her mother. He testified that he had witnessed an exchange of goods, not money, paid for him. He also told the court that, "when I saw my mother, I recognized her at once by her face." 130 There was no evidence other than Sam's testimony and the case was dismissed with no punishment laid on Ms. Quartey. ${ }^{131}$ The Aborigines Protection Society argued that these were the types of cases that encouraged the continuation of slavery in the colony. The government's inability to sufficiently punish people for slavery related offences simply encouraged the perpetuation of slavery and slave-dealing. Sam's case is particularly troubling because the Aborigines Protection Society claims that District Commissioner Peregrine refused to return Sam to the care of his mother and for the duration of the trial he was placed in the

\footnotetext{
${ }^{128}$ This story highlights the complicated nature of slavery and race in colonial Ghana and offers some insight into the way in which these cases were dealt with in the colonial courts. Ellen Quartey, being the concubine of a "white resident of Accra," was almost certainly African and quite probably a slave herself. ${ }_{129}$ British Parliamentary Papers, 1891, C-6354.

${ }^{130}$ British Parliamentary Papers, 1891, C-6354.

${ }^{131}$ British Parliamentary Papers, 1891, C-6354.
} 
care of the prison warder, as if he were an orphan child. It was not until Ellen Quartey was convicted of forcibly confining him that Sam was reunited with his mother. ${ }^{132}$

In cases in which freed slaves did 'become 'apprenticed' wards of the colonial government," they were usually no better off than those who had been returned to their convicted masters. Some children who had been freed by the courts were placed in the guardianship of the prison matrons or warders. The prisons lacked the necessary facilities to help these children transition into freedom and potentially enter the wage labour economy. In fact, Opare-Akurang suggests that some children who were placed in the care of prison officials were actually clandestinely returned to their former owners by prison officials. ${ }^{133}$

In their letter to the Colonial Office, the Aborigines Protection Society claimed that, "at no time, or only on very rare occasions has the Ordinance of 1874 been adequately enforced as regards either the liberation and careful apprenticeship of children imported into the colony and sold there as slaves or the punishment of slave dealers and slave owners."134 The Society also suggested that the colonial government was unwilling to appropriately punish those convicted of violating anti-slavery laws. They were so convinced of the government's negligence that the Society called for an inquiry into the actions of the colonial governor with regard to the administration of the Emancipation Ordinance and the Master and Servant Ordinance. ${ }^{135}$ In 1891, Fox Bourne claimed that the Aborigines Protection Society had been informed that a large number of children had

\footnotetext{
${ }^{132}$ British Parliamentary Papers, 1891, C-6354.

133 Opare-Akurang, "The Administration of the Abolition Laws," 155.

134 British Parliamentary Papers, May 1891, C-6354.

${ }^{135}$ British Parliamentary Papers, May 1891, C-6354.
} 
been taken from coastal towns into the interior following rumours that there may be an upcoming inquiry regarding the enslavement of African children. Fox Bourne suggested that once the threat had passed, the children were brought back to the coast by their masters, "as they are now under no fear of being punished and believe that all risks of having their slaves taken away from them by the government and liberated have terminated."

In response to these accusations, District Commissioner Peregrine stated that he had "always done my utmost to enforce Ordinance No. 1 of 1874 when the charge has been clearly brought before me. The difficulty in these cases is to prove actual purchases, and reliable evidence in these charges is most difficult to obtain." The Aborigines Protection Society and the colonial government clearly had two very different notions of how effective anti-slavery laws, and their enforcement, had been in the colony. Each charge that was levied against the government by the lobby group was rebuked by the official involved and excuses were made about lack of evidence in slavery related cases, lack of resources with which to find appropriate "apprenticeships", and the over-all difficulty of enforcing the law. However, in spite of the court and apprenticeship records, colonial officials did claim that they were doing the best they could to enforce antislavery and anti-slave-dealing laws.

$* * * * *$

${ }^{136}$ British Parliamentary Papers, May 1891, C-6354. 
Slavery in the British Empire varied considerably over time and location as well as in the work that was done by those enslaved. The function of enslaved peoples could be "essentially social, political or economic, or it could be some combination of these."137 Different forms of forced labour co-existed in the same societies and slavery was only one form of the exploitation of labour that was practiced alongside others, including pawnship and debt bondage. The end of slavery in the British Empire was as varied as its existence had been. ${ }^{138}$

In colonial Ghana, the condition of enslaved children was also quite varied. Some slave children attended school and were treated as part of the family. When offered the choice, some decided against emancipation. ${ }^{139}$ However, the enslavement of children often involved some form of violence. This came in the form of beatings, imprisonment and chaining. In cases in which children were being abused by their masters, British magistrates were more likely to prosecute the masters for abusing the children rather than for slavery related offences. For example, some magistrates were known to have characterized pawnship relationships as being similar to apprenticeships while also fining those people who appeared in court for abusing pawns that were under their control. ${ }^{140}$

This situation was further complicated by the fact that the colonial administration, district officials, and the colonial courts had great difficulty enforcing anti-slavery laws. It is clear that many children in the colony continued to live in slave and slave-like conditions following the Emancipation Ordinance. Cases like that of Naymie Domah and

\footnotetext{
${ }^{137}$ Paul Lovejoy, Transformations in Slavery, 9.

${ }^{138}$ Miers and Roberts, "The End of Slavery," 5-6.

139 Getz, "British Magistrates and Unfree Children," 165.

${ }^{140}$ Getz, "British Magistrates and Unfree Children," 165.
} 
Fanny Hagan are demonstrative of the complicated nature of slavery in the colony as well as the inability of colonial officials to protect the child victims of slavery and slave dealing.

As Opare-Akurang suggests, the emancipations laws were only really effective when there was relatively strong pressure from Britain and from humanitarian groups like the Aborigines Protection Society. There were many problems with the administration of the Emancipation Ordinance and the Master and Slave Ordinance. First, there were not enough government representatives for the large area in which the laws applied. Second, there was a lack of coherent policy regarding the integration of freed child slaves into colonial society. Third, many colonial officials believed that African slavery was "benign" when compared to that which had existed in the Caribbean and its existence was not offensive to them. As a result, slave holders and slave-dealers were able to exploit these weaknesses in the administration of the law and the impression that domestic slavery was not damaging to those enslaved. Thus, the enslavement of children and youth continued long after slavery and slave-dealing were made illegal in the colony.

As a result of this inability, and alleged unwillingness to prosecute slave holders and slave-dealers, missionaries, in particular those representing the Basel Mission, chose a pragmatic approach to slavery and forced labour in colonial Ghana. The unpaid labour of children, at mission stations and elsewhere, continued to be a common practice long after the official abolition of slavery in the colony. In the interior of the colony, missionaries had a great deal of influence in the lives of African children. While the missionaries were ideologically opposed to slavery, they relied on the labour of children 
to maintain the mission stations and to ensure their economic viability. The next chapter will ask questions about the nature of the missionaries' relationship with African children and the kind of work they were required to perform at mission stations in the interior of the colony.

The Basel Missionaries expressed some of the same sentiments as the Aborigines Protection Society when they attempted to report instances of slavery and slave dealing to colonial officials. The efforts of both of these groups, the Basel Mission's own use of children as labourers and the colonial administration's inability to deal with the continued existence of slavery and slave dealing in the region are indicative of the complicated nature of child labour and the difficulty of enforcing anti-slavery laws in the colony. While ideologically opposed to slavery in all its forms, the Basel Mission often relied on the labour of unpaid children. These children were largely students at the mission schools who split their time between general education, Bible study and unpaid labour. The missionaries had a strong desire to 'civilize' Africans through Christianization and the re-organization of labour to reflect what they viewed to be European Protestant values. However, on a more practical level, they required the labour of African children in order for the mission stations to be economically sustainable. The conflict between the missionaries' philosophical opposition to slavery and their need to support the continued growth of the Mission through trade, led to a complicated relationship between the members of the Basel Mission and African children. 


\section{Chapter Two - Saving the Children from "Perdition": Child Labour and the Basel Mission}

As discussed in the first chapter, anti-slavery legislation did not end the enslavement of

children in colonial Ghana. In fact, as it became more difficult to use the forced labour of adults, children and youth were even more vulnerable to exploitation, In colonial Ghana, missionaries had a great deal of daily interaction with African children, particularly those living in the less regulated interior of the colony. As evidenced in the records of the Basel Mission's experience in colonial Ghana, children were often an important focus of the Christianization initiative, as well as a source of all-important labour for mission construction, maintenance, agriculture, and the production of trade commodities. As a result, children's labour, and indeed African childhood itself, was an important point of contestation between mission authorities and local African communities. The goal of this chapter is to complicate the narrative of labour history in colonial Ghana and the systems of child labour employed by the Basel Mission between 1855 and 1914 when most of the missionaries were expelled from the colony.

The correspondence records of the Basel Mission speak to its effort to redefine African childhood, as well as the importance it placed on the acquisition of African children as both Christian converts and as labourers. Through their education at Basel Mission schools, their eventual baptism, and their training and work experience at the mission stations, African children were being carefully prepared for a future that emphasized colonial and missionary values and attempted to reduce the influence of 
African communities. The archived documents reveal that the missionaries associated with the Basel Mission recognized that access to African children better enabled them to achieve the over-all objectives of the "missionary project."

The Basel Mission was ideologically opposed to all forms of slavery; however, their correspondence records indicate that they often used the labour of unpaid children to perform tasks such as carpentry, weaving, sewing, metalwork, agricultural tasks and housework. A great deal of the labour on mission stations was performed by unpaid children who also attended school and Bible lessons at the mission. The interaction and relationship between members of the Basel Mission and African children in colonial Ghana was largely one of ambiguity. At times missionaries saw themselves as liberators, but this discourse of liberation and paternalism was grounded in certain assumptions of European superiority and the desire to 'civilize' Africans. These assumptions informed their ideas about how African child labour should be used. This chapter argues that despite the abolitionist tendencies of missionaries, they, in fact, played a very complicated role in mediating the exploitation of child labour through established African institutions such as slavery, pawnship and debt bondage. While children were present on cocoa and coffee plantations in the region, this research explores the roles children played on mission stations and their interaction with members of the Basel Mission in colonial Ghana.

The Mission's primary function in colonial Ghana was that of a trading company, and as a result, African children were trained in the type of work that could benefit the missionaries in this capacity. Mission records reveal that African boys worked as 
carpenters, sawyers, weavers, and agricultural labourers. African girls were also used as agricultural labourers, but more often they were trained in sewing, crocheting, mending, cooking, and cleaning. ${ }^{141}$ The way in which the missionaries used children as labourers often reflected traditional European gender roles that were not necessarily compatible with those of nineteenth century Ghana.

\section{Historical Context: Early Colonial Ghana and the Basel Mission}

As mentioned earlier, during the early nineteenth century, the West African economy underwent some important changes. As the Atlantic slave trade was abolished, the focus shifted from the export of slaves to trade in agricultural products like palm oil, palm kernels, cocoa and other "legitimate trade" items. ${ }^{142}$ These economic changes had social consequences which led to the increased use of slaves and pawns in local West African economies. $^{143}$

The religious ideology of the Basel Mission Society grew out of the churches of southern Germany and Switzerland. "Wurttemburg Pietism" as it was referred to, included "a strong commitment to missionary evangelism, and the Basel organization played visible and important part in the overseas missionary movement that accompanied the economic and cultural expansionism of nineteenth century Europe."144 The Mission Institute operated out of a seminary in Berlin until the Napoleonic Wars and the blockade

\footnotetext{
${ }^{141}$ Ghana Archive of the Basel Mission (BM). Series D-12, Reels 129 \& 130.

${ }^{142}$ Lovejoy, Transformations in Slavery, 159.

${ }^{143}$ Lovejoy, Transformations in Slavery, 160.

144 Jon Miller, Missionary Zeal and Institutional Control: Organizational Contradictions in the Basel Mission on the Gold Coast, $1828-1917$ (Wm. B. Eerdmans Publishing Co: Grand Rapids, MI, 2003). 13-14.
} 
of Germany in the early nineteenth century made it impossible to continue and in 1816, the Mission Institute's headquarters was moved to Basel, Switzerland, and subsequently evolved into the Basel Mission Society. However, it remained essentially a German institution and most of its recruits continued to come from Wurttemberg, Germany. Following its migration to Basel, the Mission continued to train its recruits according to the Calvinist and Pietist principles of work, discipline and orderliness and they kept themselves informed with regard to political and intellectual developments with Europe as well as developments in the colonies. ${ }^{145}$

At the height of western missionary activity, there existed a deeply ingrained belief that sending missionaries abroad was essential. The movement to abolish slavery and the slave trade had created "a sense of shared humanity" and Christian people, particularly evangelical Protestants, felt they had an obligation to spread the message of the gospel to former slaves. ${ }^{146}$ Thus, the effort to "civilize" Africans became a fundamental feature of European religious societies. ${ }^{147}$ Historian of African Christianity, T. Jack Thompson, argues that by the second half of the nineteenth century, photographs taken by European missionaries in Africa were vital tools "in the ideological armoury of the mission society at home."148 Essentially, missionary photography contributed to the idea that Africa and Africans were inherently inferior to Europeans "technologically. . .

\footnotetext{
${ }^{145}$ Seth Quartey, Missionary Practices on the Gold Coast, 1832-1895: Discourse, Gaze \& Gender in the Basel Mission in Pre-Colonial West Africa. (Youngstown, NY: Cambria Press, 2007). 23-24.

${ }^{146}$ Michael N. Barnett. Empire of Humanity, Chapter 3, 57-75.

${ }^{147}$ Elliott Kendall, The End of an Era: Africa and the Missionary (London: S.P.C.K, 1978), 5-10.

${ }^{148}$ T. Jack Thompson, Light on Darkness? Missionary Photography of Africa in the Nineteenth and Early Twentieth Centuries (Grand Rapids, MI and Cambridge, 2012), 2.
} 
culturally, morally and religiously." ${ }^{149}$ Thompson argues that these photographs played a crucial role in engendering European popular support for the missionary effort on the African continent, while also shaping European stereotypes of what Africa and Africans were like. One method through which these kinds of images were disseminated to a popular audience in Britain was the collaboration of abolitionist and missionary groups. As Michael Barnett argues, abolitionist and missionary interests drew upon and learned from each other as part of a larger humanitarian imperialist effort. ${ }^{150}$

The large Christian population in Africa today is evidence of the enduring effects of the "Christianization" of the continent, a process in which the Basel Mission Society was deeply involved. Europeans were familiar with the West African coast by the lateeighteenth century, because of their involvement in the Atlantic slave trade, but they had not yet begun significant missionary work there. In some cases, slaves were encouraged to take part in Christian religious activities, but there was no real missionary presence among the local populations. ${ }^{151}$ Early attempts to establish missionary settlements were often decimated by disease: the missionaries died before they could make any significant inroads in the evangelization of the African population. ${ }^{152}$

The original policy of the Basel Mission Society in Switzerland was not one of direct involvement in colonial activity, but they did send some recruits to aid in the efforts of Protestant Dutch mission societies in West Africa. ${ }^{153}$ By 1828, Basel Mission authorities had decided that they needed to send their own recruits to the colonial world

\footnotetext{
${ }^{149}$ Thompson, Light on Darkness? 36.

${ }^{150}$ Michael N. Barnett, Empire of Humanity, Chapter 3, 57-75.

${ }^{151}$ Kendall, The End of an Era: Africa and the Missionary, 5-19.

${ }^{152}$ Quartey, Missionary Practices on the Gold Coast, 20-24.

${ }^{153}$ Quartey, Missionary Practices on the Gold Coast, 24-27.
} 
and in December of that year its first representatives were sent to West Africa. ${ }^{154}$ All four of the men who arrived in 1828 were dead by August 1829 and a second group, which arrived in 1832, was dispatched to continue the work of their deceased brothers. ${ }^{155}$ The Basel Mission opened its first seminary in Christiansborg in 1843, where it trained teachers and assistant preachers. By 1848, it had established an additional seminary in Akropong, as well as a number of primary schools for African children. In 1867, the Basel Mission opened its first middle school for students who had aged out of the elementary schools, but were still not ready to enter the seminaries. ${ }^{156}$ It was stretched thinly at times, but the Basel Mission's presence and influence in was uninterrupted until the First World War. ${ }^{157}$ Following the outbreak of the war, the British colonial government became uncomfortable with an essentially German mission operating in its territory and in 1917 all German members of the Basel Mission (twenty-nine out of thirty-seven members) were deported. ${ }^{158}$ The mission's entire infrastructure of villages, schools, churches, farms, trading posts, stores, and workshops were placed under the control of the United Free Church of Scotland. ${ }^{159}$ Thus, the influence of the Basel Mission in colonial Ghana did not continue with the same impact beyond the early twentieth century.

\footnotetext{
${ }^{154}$ Miller, Missionary Zeal and Institutional Control, 14.

${ }^{155}$ Quartey, Missionary Practices on the Gold Coast, 24-27.

${ }^{156}$ Agbeti, West African Church History Volume II, 36-40.

${ }^{157}$ Miller, Missionary Zeal and Institutional Control, 15.

${ }^{158}$ J. Kofi Agbeti, West African Church History Volume II: Christian Missions and Theological Training 1842-1970, (Leiden. NL: Brill, 1991). 47-48.

${ }^{159}$ Miller, Missionary Zeal and Institutional Control, 15.
} 


\section{The "Missionary Project": Reshaping African Childhood}

Nineteenth century mission societies were determined "to influence the course of social change beyond the boundaries of their own societies." ${ }^{\prime 60}$ In some cases, this meant the transformation of indigenous lives, including social and cultural institutions. In other cases, the missionaries worked to preserve and maintain some aspects of indigenous culture and beliefs while doing away with others. ${ }^{161}$ In colonial Ghana, the European "civilizing mission" was reflected in the missionaries' condemnation of African social and cultural practices and their efforts to Christianize and "modernize" African people. ${ }^{162}$ In his work on the history of humanitarianism, Barnett suggests that while European missionaries often held varying opinions regarding non-Western and non-white peoples, they did recognize a shared humanity. He argues that the "missionary project" could only have been sustainable if a notion of "the fundamental unity of humanity" existed. ${ }^{163}$ According to Barnett, abolitionist and missionary efforts drew both inspiration and knowledge from each other. Nineteenth century imperial humanitarians believed that colonialism, Christianity, and commerce "could provide the will and the way to emancipate slaves, save sinners and souls and position backward societies on the path to civilization." ${ }^{164}$ This cultural, religious, and economic paternalism guided the actions of

\footnotetext{
${ }^{160}$ Miller, Missionary Zeal and Institutional Control, 11.

${ }^{161}$ Miller, Missionary Zeal and Institutional Control, 11.

162 Barnett, Empire of Humanity, Chapter 3, 57-75. In his 2012 book Slavery by Any Other Name, Eric Allina shows that colonial subjects in Mozambique were often forced the work on projects aimed at building roads, bridges and other infrastructure for the Companhia de Moçambique as well as on European farms and mines. As in colonial Ghana, this was part of the "civilizing mission." (Eric Allina, Slavery by Any Other Name: African Life Under Company Rule in Colonial Mozambique. (Charlottesville: University of Virginia Press, 2012).

${ }^{163}$ Barnett, Empire of Humanity, Chapter 3, 57-75.

${ }^{164}$ Barnett, Empire of Humanity, Chapter 3, 57-75.
} 
the Basel missionaries in colonial Ghana as they established schools, churches, and farms throughout the region.

\section{Objectives of the Basel Mission}

In colonial Ghana, the "civilizing' aspect of the "missionary project" was articulated in the missionaries' condemnation of African social and cultural practices. In communities in which the Basel Mission maintained a strong presence, the missionaries instituted rules regarding what kind of behaviour was considered acceptable. In particular, the missionaries were interested in the creation and maintenance of 'good Christian families.' In 1871, the Mission authorities in Switzerland enquired as to the life of African Christian couples in the region; specifically, they wanted to know whether they ate and prayed together regularly. In response, the missionary Haas, who reported from various mission stations and schools in colonial Ghana, explained that this was difficult for the missionaries to confirm because, "there is no order about the way they live" and they, naturally, "act much differently in the presence of the missionaries". ${ }^{165}$

In addition to his response to the question about African couples, Haas expressed concern about the relationship between African parents and their children. The missionaries' understood the family dynamic as one in which children in were viewed in terms of the monetary value they could bring to their families and that they did not "belong to their parents, but to the wife's family."166 In many cases African families and

\footnotetext{
${ }^{165}$ BM Series D-12, Reel 130 (1871).

${ }^{166}$ BM Series D-12, Reel 130 (1871).
} 
kinship groups were organized primarily along matrilineal lines. However, it was also somewhat common for people to be brought into the group from outside. This was particularly common in case of the assimilation of slaves into the family group. This type family structure as was confusing to European missionaries and colonial officials and in the case of the Basel Mission, they often attempted to circumvent it. ${ }^{167}$ He suggested that unless this system could be broken down, the development of Christian family life would be virtually impossible in the region. ${ }^{168}$ Haas' reflections about marriage, family and childhood suggest that members of the Basel Mission understood children to be extremely important to their work in the region. In his view, raising children in an environment that more closely mimicked the social and cultural practices of Western Europe was essential to the successful development of Protestantism in the colony. Haas believed that in order to foster the ideals of Christian family life in colonial Ghana, it was necessary to break down existing African family structures. Additionally, his concern suggests that the labour of African children would be much easier to exploit if the Mission was successful in breaking down traditional societal structures. ${ }^{169}$

In order to separate African children from their parents and families, the missionaries advocated for children's boarding schools at the mission stations as opposed to day-schools. They argued that African children were "industrious and learn well, but their character and life is not satisfactory" because they were being raised by "pagans,

\footnotetext{
${ }^{167}$ Getz and Clarke. 99-100.

${ }^{168}$ BM Series D-12, Reel 130 (1871).

${ }^{169}$ BM Series D-12, Reel 130 (1871).
} 
among pagans."170 This would have also given the missionaries more control over the type of labour African children undertook and ensured that the type of work they were doing could be shaped by the missionaries themselves. If children attended school only four or five days each week for only part of the day, their families would have maintained a significant degree of control over their labour power and the Basel Mission would have had less control over the pupils. Parintha Shetty argues that in colonial Mangalore, India, education was considered essential to the Christianising mission and Basel Mission boarding schools "enabled missionaries to house orphans, separate children of converts from their 'far from satisfactorily converted' parents, wield complete pedagogic control over their students, and create a space that would be rid of all heathen influences." ${ }^{171}$ It is reasonable to suspect that the Basel Mission pursued similar objectives in Ghana.

The Basel missionaries believed that moral corruption was rampant in African culture and because of this there should not only be separate Christian quarters within African towns, but entirely separate villages for African converts. If segregated villages were established, African children would be "brought up properly" and it would be much easier for the Mission to educate and train the children. ${ }^{172}$ Andreas Riis, one of the founding members of the Mission's initiative in colonial Ghana, stated that for the missionaries, "there is nothing more blessed than the snatching of children from perdition". ${ }^{173}$ Members of the Basel Mission viewed all contact with non-Christian

\footnotetext{
${ }^{170}$ BM Series D-12, Reel 129 (1880).

${ }^{171}$ Parintha Shetty, "Missionary Pedagogy and Christianisation of the Heathens: The Educational Institutions Introduced by the Basel Mission in Mangalore." The Indian Economic and Social History Review 45, 4 (2008): 509-51. 521.

${ }^{172}$ BM Series D-12, Reel 129 (1880).

${ }^{173}$ BM Series D-12, Reel 129 (1880).
} 
family and community members as being potentially dangerous to African children because, in their view, they returned to the mission station "with evident damage to their souls." ${ }^{.174}$ After the holidays, during which time students were permitted to return to their families, many of them did not come back to the mission station and the missionaries assumed that some of these children had been pawned by their "heathen" parents. ${ }^{175}$ However, it is equally likely that parents decided that they no longer wanted to give the missionaries absolute control over their children and decided against long periods of separation. $^{176}$

One problem that members of the Basel Mission encountered, regardless of location, was the issue of how to insert their particular brand of Protestant Christianity into societies in which other religious customs and traditions were already entrenched. A solution to this problem was the establishment of schools at mission stations. Through the education of children, Protestant Christian values could be instilled in African communities and the missionaries could alter or re-orient local economies through the labour of pupils. ${ }^{177}$

\footnotetext{
${ }^{174}$ BM Series D-12, Reel 129 (1884).

${ }^{175}$ BM Series D-12, Reel 129 (1884).

${ }^{176}$ Similarly, in colonial India, members of the Basel Mission worried about sending students home during the holidays. As a solution, students who were being trained in giving sermons and preaching would be required to accompany the missionaries on preaching expeditions. The missionaries hoped that the boys would provide a positive example of the disciplined and religious community offered by the Basel Mission. In addition, preaching tours were an occasion to test the students on their ability to answer questions from non-Christians and for them to listen to, and memorize, sermons given by Basel Mission members (Shetty. "Missionary Pedagogy." 520.)

${ }^{177}$ In India, they also had to be cognizant of being mistaken for followers of Catholicism, a religion already familiar to the people of places like Mangalore (Shetty, "Missionary Pedagogy," 511.)
} 


\section{The Basel Mission and Unfree Children}

Mission societies in Africa were opposed to the slave trade and in many cases they were closely associated with the abolition of the Atlantic slave trade. Wherever European missionaries travelled, they carried the message that slavery and slave-trading were morally abhorrent. ${ }^{178}$ However, their actions and policies often contributed to the justification of lenient policies regarding slavery in colonial Ghana. ${ }^{179}$ They considered the eradication of slavery to be an important part of their civilizing and Christianizing mission, however, they also felt that conversion of Africans to Christianity should take priority over abolition efforts. Essentially, slavery was deemed to be tolerable until the Church was firmly established. ${ }^{180}$

In colonial Ghana, missionaries often had to accept slavery, pawning and debt bondage in the communities in which they established their missions. In the case of the Basel Mission, the missionaries took advantage of the continued existence of slavery when it suited their needs. In order to build mission stations, churches and schools they usually required the support of local elites who were typically holders of slaves or pawns and an uncompromising opposition to slavery was sometimes not an option. ${ }^{181}$ Additionally, they required a large number of labourers in order to actually build mission institutions. Free labour was often not available and the missionaries had to employ

\footnotetext{
${ }^{178}$ Miers, Ending of the Slave Trade, 153-154.

${ }^{179}$ Lovejoy, Transformations in Slavery, 253.

${ }^{180}$ Lovejoy, Transformations in Slavery, 245.

${ }^{181}$ Getz, Slavery and Reform, 61.
} 
slaves and pawns. Thus, their anti-slavery idealism gave way to pragmatism and contributed to the perpetuation of slavery in the colony. ${ }^{182}$

The use of children as labourers was quite common in colonial Ghana. In traditional African societies in the region, families were organized through a central household which was made up of descendants of a common ancestor and controlled by one elder. This head of household was responsible for using the land under his control in a way that would ensure the success of the entire family group. Children, as dependents, would have been required to perform domestic and agricultural tasks within the family. ${ }^{183}$ The Basel Missionaries relied on local African communities to provide them with the labour necessary for initiatives like these. Some students lived with missionaries and worked as domestic servants while others laboured in fields and gardens. ${ }^{184}$

The members of the Basel Mission viewed the practice of slavery in colonial Ghana as being one of the "evils of a heathenistic society." 185 For example, the Basel missionary Obrecht reported that one African man who had been under baptismal study had to have his baptism postponed because he had undertaken a slave-selling expedition into Akwapim on behalf of a "non-Christian" friend from Abetifi. He had reportedly taken a child from Akwapim whom he later sold on behalf of a friend for between five and ten pounds. Obrecht claims that the missionaries advised him to undo the sale of the child or else they would report him to the colonial government. ${ }^{186}$ However, in most cases in the early colonial period, the Basel missionaries rarely went beyond simply

${ }^{182}$ Getz, Slavery and Reform, 61.

${ }^{183}$ Coe, "How Debt Became Care," 289.

${ }^{184}$ Coe, "How Debt Became Care," 292.

${ }^{185}$ Peter Haenger, Slaves and Slave Holders, 18.

${ }^{186}$ BM Series D-12, Reel 130, (22 January 1898). 
condemning slavery as a sin. ${ }^{187}$ The congregations of the Basel Mission initially consisted of "alienated or peripheral members of the community," but as the mission became more established, the missionaries began to reject any potential converts who were slave owners or slave dealers and who refused to extricate themselves from the practice. $^{188}$

Members of the Basel Mission treated slavery not as the product of a complex social structure, nor did they contemplate the ways in which European involvement in the Atlantic slave trade led to slavery in Africa. They viewed it as simply a "heathen problem" which they believed would cease to exist once they had succeeded in converting the population to Christianity and established the Protestant Church in the colony. ${ }^{189}$ Ironically, as part of their abolitionist efforts, the Basel Mission did occasionally purchase slaves so that they could live at the mission as "free" Africans. ${ }^{190}$ The liberated slaves, however, were expected to work off the cost of their purchase through the performance of various duties assigned by the missionaries. ${ }^{191}$ Johannes Muller noted that the formerly enslaved rarely felt obligated to work for the missionaries who purchased their freedom. ${ }^{192}$ Blinded by their own prejudices, the missionaries were

\footnotetext{
${ }^{187}$ Haenger, Slaves and Slaveholders, 18.

${ }^{188}$ Getz, Slavery and Reform, 62.

${ }^{189}$ Haenger, Slaves and Slaveholders, 18.

${ }^{190}$ It was not commonplace for missionaries to purchase African slaves as a means through which to grant their freedom. The missionaries believed that this practice simply contributed to the perpetuation of slavery. However, they were not the only mission society to do so. Between 1857 and 1867, the Bremen Mission (also known as the North German Missionary Society) in colonial Ghana purchased one hundred and nine slave children. Their stated goal was to give the children a Protestant upbringing and train them as labourers, teachers, interpreters, preachers and catechists. (Sandra E. Greene, West African Narratives of Slavery: Texts from Late Nineteenth- and Early Twentieth-Century Ghana. (Bloomington: Indiana University Press, 2011). 143).

${ }^{191}$ Greene, West African Narratives, 143.

${ }^{192}$ BM Series D-12, Reel 130 (1893).
} 
unable to draw parallels between their expectation that these newly "freed" Africans should be required to work for them, and that of the African system of debt bondage. There are numerous complaints in the Basel Mission correspondence that describe "ungrateful subjects" who did not want to work for the missionaries and simply "ran off" or "returned to the households of their former masters." 193

After 1874, the missionaries sometimes encouraged slaves who lived in their communities to leave their masters and seek refuge at the mission station. This included both adults and children. Many of the adults who settled with the Basel Mission did not stay long, but running away was much less common in the case of former slave children. ${ }^{194}$ The missionaries interpreted the actions of adults who left as being reflective of their ungrateful attitude toward the missionaries. However, it is entirely likely that the adults who left the mission stations did so in order to re-unite with their families in other regions. Or, even more simply, perhaps they did not wish to be a part of the Protestant lifestyle which was strictly enforced at the mission stations. Former slave children often did not have the ability to return to their families, and as a result, members of the Basel Mission were able to take advantage of their labour in a way they were unable to do with adults.

In some cases, members of the European missionary societies purchased slaves and expected them to pay off the cost of the purchase through labour. ${ }^{195}$ The Wesleyans, for example, tried to ameliorate the situation by buying the contracts that bound slaves

\footnotetext{
${ }^{193}$ Haenger, Slaves and Slaveholders. 49; BM Series D-12, Reel 129 (1893).

${ }^{194}$ BM Series D-12, Reel 130 (1893).

${ }^{195}$ Getz, Slavery and Refor, 61.
} 
and pawns to their masters. They paid the "freed" slaves a wage for their labour, but deducted a certain amount until the cost of purchasing their contract had been paid. Getz suggests argues that "there was a fine line between liberating slaves through purchase and purchasing slaves for labour, and the missionary groups were sometimes forced to operate on the "wrong" side." 196 The missionaries were clearly aware of this line, but there was some discussion in their correspondence with headquarters over what constituted crossing it.

A series of correspondence from May of 1893 among a number of Basel Missionaries stationed in the colony indicates that they had seriously considered buying slave children and allowing them to live at the mission station as free people, provided that they paid for their freedom with their labour. ${ }^{197}$ This is reflective of the fact that, for the Basel Missionaries, ending slavery was not the primary objective. The goal of abolition was secondary to the Christianization of the African population and the economic sustainability of the mission stations. Hence, missionaries were willing to use the unpaid labour of African children to support the mission and to build the congregation.

Overall, the missionaries who commented on this proposal were against the idea of buying large numbers of slaves who would then live at the mission station. They were much more comfortable with the proposed scheme of using the mission station as a type of refuge for slaves who had willfully run away from their masters. ${ }^{198}$ The missionary

\footnotetext{
${ }^{196}$ Getz. Slavery and Reform, 61.

${ }^{197}$ BM Series D-12, Reel 130 (1893).

${ }^{198}$ BM Series D-12, Reel 130 (5 May 1893).
} 
Friedrich Ramseyer believed that if they bought slave children, the missionaries would be contributing to the stimulation of slave trafficking in the region, which he was not in favour of doing. If they did not purchase slave children, Ramseyer did not understand how they would attract them to the mission station. For Ramseyer, the most desirable option was to set up a space for slaves who had escaped their masters on their own. ${ }^{199}$

Colonial administrators were largely ambivalent regarding the enforcement of anti-slavery laws and they relied heavily upon alliances with indigenous elites whose social and political power was generally derived from the ownership of slaves and access to the labour of pawns and other dependants. ${ }^{200}$ It is, then, not surprising that when the Basel Mission did attempt to report instances in which children were being pawned or enslaved, little action was taken against those involved. Muller reported to Basel in 1895 that at one time, the laws over slavery and pawnship were vigorously pursued by the colonial regime, but for about ten years "officials have left people in peace and administered the slavery law in a very superficial way. ${ }^{201}$ Muller gives the example of a case in the 1880s in which the Anum chief received seven boys as pawns as a result of a debt someone in Buem had incurred. Muller reported this incident to the district official who said that the boys were in good hands and took no real action against the chief. ${ }^{202}$

Another case occurred in Akropong in which a number of boys were given to the local chief as pawns. In this case, the district official did free them when an accusation was made, but no punishment was levied on those who had been involved in pawning the

\footnotetext{
${ }^{199}$ BM Series D-12, Reel 130 (5 May 1893).

${ }^{200}$ Miers and Roberts, "The End of Slavery," 17.

${ }^{201}$ BM Series D-12, Reel 130 (1895).

${ }^{202}$ BM Series D-12, Reel 130 (1895).
} 
boys. According to Muller, pawning remained relatively common and he suggests that there were many cases in which pawns ran away from their masters' homes and left their families to pay the debt. ${ }^{203}$ He reports, to his disappointment, that Christians were also involved in pawning. The people in the African Christian community, particularly in the more remote farming villages, owned slaves and pawns to an extent that Muller deemed would have been very difficult to stop. He laments that in order to root out all instances of slavery, formal investigations would have to have been held in each individual case, something that he did not believe the colonial administration would have been willing to do. $^{204}$

The closely held moral objection that missionaries had toward slavery and the practical reality that they required labourers in order for the mission stations to function, complicated their role in the colony. This dilemma prompted the Wesleyan Mission in Cape Coast to advocate for a "capitalist mode of labour in order to 'assist in creating a market-force economy to free slaves.",205 They believed the promotion of cash crop farming would encourage the growth of wage labour and in their effort to eliminate slavery they instituted programs to promote the production of crops like cotton. These schemes ultimately failed and Getz suggests that it was because "the Gold Coast was not ready for the wage labour revolution."206

\footnotetext{
${ }^{203}$ BM Series D-12, Reel 130 (1895).

${ }^{204}$ BM Series D-12, Reel 130 (1895).

${ }^{205}$ Getz, Slavery and Reform, 62.

${ }^{206}$ Getz, Slavery and Reform, 62.
} 


\section{Child Labour at Basel Mission Schools}

In colonial Ghana, the arena in which the Basel Mission had the most direct and sustained access to African children was at mission schools. Freed adult labourers often left the mission station, making it difficult for the Basel Mission to secure the consistent paid labour of adults. ${ }^{207}$ Children, on the other hand, were present at mission schools where they were engaged in various kinds of domestic and agricultural labour. During the second half of the nineteenth century, the Basel Mission established stations and schools in various parts of the interior in an effort to establish the Protestant religion. The Mission's quarterly and annual reports offer insight into the missionaries' approach to the education and Christianization of African children, as well as the ways in which they attempted to control their labour.

In an 1897 report from the Abetifi Mission School, in the Eastern Region, missionaries described African children as being similar to European children, but "a bit

more stubborn and crafty." ${ }^{208}$ They reported that the students, who were also labourers at the mission station, had been instructed to plant a maize farm but the task was completed only after they had been placed under "constant supervision." ${ }^{209}$ Furthermore, the report indicates that the fence surrounding the maize fields was constructed "so badly and looked after so pathetically that there was no harvest at all" because it failed to keep out sheep and goats and they consumed the maize before it matured. ${ }^{210}$

\footnotetext{
${ }^{207}$ Getz, Slavery and Reform, 61.

${ }^{208}$ BM Series D-12, Reel 130 (1897). There were 106 pupils enrolled at this school (twenty-six girls and sixty-five boys).

${ }^{209}$ BM Series D-12, Reel 130 (1897).

${ }^{210}$ BM Series D-12, Reel 130 (1897).
} 
The author of this report concluded that, "African boys have little interest in working" and will only do so when they are constantly monitored. ${ }^{211}$ The missionaries noted that it was difficult for teachers at the schools to impress upon African children the importance of the work they were required to do at the mission stations. In their correspondence with headquarters in Switzerland, mission representatives declared that their goal was to "make these youths not only Christian and pious, but hardworking members of their nation and follow[ers] of evangelical principles."212

This dissatisfaction felt by members of the Basel Mission regarding the "work ethic" of African children and the quality of the work they performed provokes a number of questions. Did the missionaries show the children how to construct fences the way they wanted? Did the children understand the function the fence was meant to serve? Is it possible that what the missionaries perceived to be stubborn and lazy behavior was actually an attempt by the children to resist being controlled by the missionaries? Similarly, is it also possible that building a poor enclosure was an attempt to sabotage the corn crop as a form of rebellion? Or, were the children merely being children and engaging in play?

\footnotetext{
${ }^{211}$ BM Series D-12, Reel 130 (1897).

${ }^{212}$ BM Series D-12, Reel 130 (1897).
} 


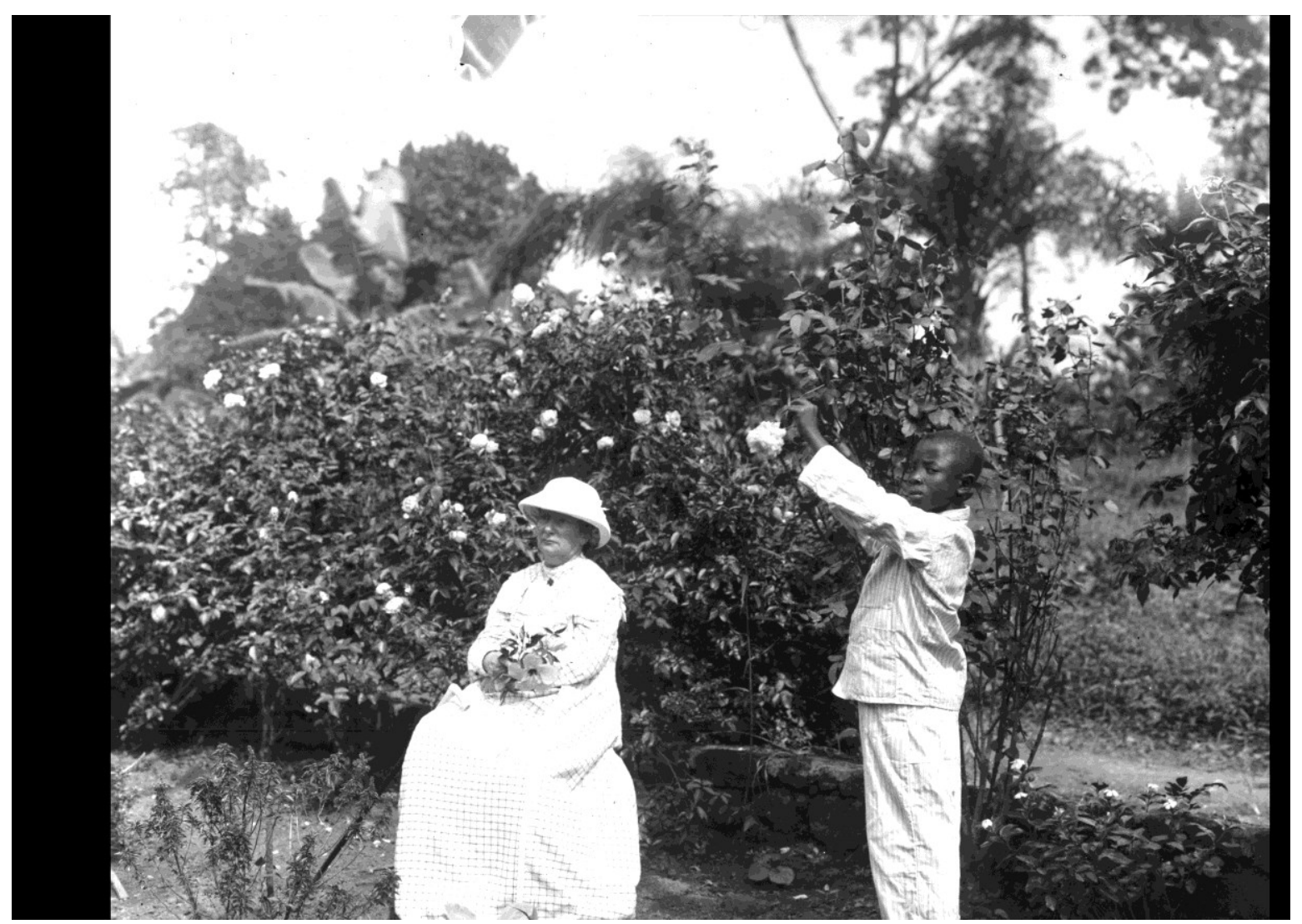

[photo caption:"Mrs. Ramseyer and a houseboy picking roses in the garden,” c. 1896$1906 .^{213}$ Rosa Luise Ramseyer was stationed in the Abetifi region of colonial Ghana where pupils performed various domestic tasks in addition to working in the fields and gardens at the mission station. ${ }^{214}$ ]

Children represented the future of the colony and the missionaries wanted to educate and train them in a way that would benefit the Basel Mission itself. Training African children in the Calvinist tradition and teaching trades such as carpentry, weaving, and farming helped to bind children to the Mission through their youth and adulthood.

\footnotetext{
${ }^{213}$ Basel Mission Archives / Basel Mission Holdings, QD-32.024.0138. Taken by Rosa Luise RamseyerBontems c. 1896-1906 in Ghana.

${ }^{214}$ BM Series D-12, Reel 130 (1897).
} 
For example, the reports indicate that the missionaries elected not to plant many native fruits and vegetables; rather they preferred to concentrate on things like coffee and cocoa, which were not traditionally planted by the local people. ${ }^{215}$ Both coffee and cocoa require a significant amount of labour, much of which would have been done by students at the mission schools. The production of coffee and cocoa by Basel missionaries in the colony was linked to the larger expansion of the cash crop economy associated with the demand from external markets. ${ }^{216}$

As Beverly Grier has shown in her study on colonial Zimbabwe, children represented a significant challenge to both missionary and colonial authority. African children were fully capable of negotiating the terms of their labour, withholding it, and resisting its devaluation at the hands of the missionaries. For example, in 1884, at the Basel Mission boarding school in Abetifi, the missionaries decided to end their monetary support for the level four class and resolved that clothing would be distributed to all pupils only once per year. This resulted in what the Mission records describe as a "revolt" that manifested in a "breakdown of relations between the house father in the school and the pupils." 217 During this "revolt," the children "refused to work for their lesson." 218 When they did work, they "deliberately set out to annoy [the housefather] by their laziness, and if he punished any of them they simply ran away."219 As a result of the large number of children who left, and presumably returned to their families, the Mission

\footnotetext{
${ }^{215}$ BM Series D12, Reel 129 (1858).

${ }^{216}$ Inez Sutton, "Labour in Commercial Agriculture in Ghana in the Late Nineteenth and Early Twentieth Centuries," Journal of African History 24, (1983): 461-483. 465.

${ }^{217}$ BM Series D-12, Reel 129 (1884).

${ }^{218}$ BM Series D-12, Reel 129 (1884).

${ }^{219}$ BM Series D-12, Reel 129 (1884).
} 
ended up closing the Abetifi boarding school later that year. ${ }^{220}$ Ulrike Sill suggests that the pupils ideas about changes like those that incited the Abetifi "revolt" were informed by their experience in their local communities and their familiarity with relationships of dependency. Parents complained that their children who were registered at mission schools only received food and clothing from the schools. ${ }^{221}$ Sill argues that parents, and perhaps also children, thought that pupils at the schools were being treated like slaves because slaves, received food and clothing from their masters. ${ }^{222}$

There were also instances in which members of the Basel Mission, in their attempt to exploit the labour of African children, disregarded existing social and cultural practices which resulted in conflict with the local people and the loss of child labourers. In the Begoro region in 1878 , the Basel Mission experienced a great deal of trouble recruiting children for its school. According to Basel Mission correspondence, the local people were afraid of Christianity and they worried that if a child went to school the family would "be visited by ill-luck or death" and the child would leave the family prematurely. ${ }^{223}$ In the case of girl children, the missionaries attributed African parents' reluctance to send them to school to a concern that they would not be able to marry as early as they might if they did not go to school. ${ }^{224}$

The missionaries appear to have attributed African unwillingness to send their children to school to the fact that the majority of them had not yet converted to Christianity and were, therefore, skeptical of its influence. In the missionaries'

\footnotetext{
${ }^{220}$ BM Series D-12, Reel 129 (1884).

${ }^{221}$ Sill, Encounters in Quest of Christian Womanhood, 299-300.

222 Sill, Encounters in Quest of Christian Womanhood, 300.

${ }^{223}$ BM Series D-12, Reel 129, (1878).

${ }^{224}$ BM Series D-12, Reel 129, (1878).
} 
estimation, African parents were exhibiting an irrational degree of apprehension regarding their children's attendance. ${ }^{225}$ The missionaries did not consider that families were dependent upon the labour of their children for survival and that African parents may not have trusted the missionaries to care for their children properly.

Another example of this conflict over the labour of children occurred in Begoro in the 1880s. In this case, there were clashes between local Africans and the Basel Mission over whether the boys who were enrolled in school should be permitted to leave for the duration of snail hunting season so they could help their families. ${ }^{226}$ A meeting of local African families decided that they would only send their children to the mission school if they were compensated for their children's labour each month. ${ }^{227}$ This demand for payment by African parents was not confined to the Begoro region; in 1884, Johannes Tschopp, a member of the Basel Mission, reported that he was frequently badgered by parents and relatives of boys at the Abetifi school who wanted money from the missionaries. He notes that he had even been asked for four pounds, "the usual price of a man." 228 This suggests two very interesting things. Firstly, the Basel Missionaries were using children's labour in a way that was incompatible with existing systems and schedules of labour. Secondly, African parents, families, and the community in general, were losing a traditionally important component of their collective labour force. Thus, they felt they should be compensated because control over the labour of their children, and the profits garnered from their labour, were essential to the mission's survival.

\footnotetext{
${ }^{225}$ BM Series D-12, Reel 129 (1878).

${ }^{226}$ BM Series D-12, Reel 129 (1878).

${ }^{227}$ BM Series D-12, Reel 129 (1878).

${ }^{228}$ BM Series D-12, Reel 129 (1884).
} 
There were also instances in which African youth were able to organize

themselves in order to dictate the terms of their labour. In August 1876, there was a strike of the Basel Mission's unskilled adult and youth labour force in Begoro. At the time, the supply of this type of labour in the region was greater than the missionaries' need for labourers enabling them to reduce wages and offer employment only to those who were willing to work for significantly lowered pay. ${ }^{229}$ Soon after the wages had been cut, "no boys came to work" and the missionaries heard that, "they had sworn an oath or made a law that no further work should be done unless the old payment. . was revised." ${ }^{, 230}$ The strike carried on for two weeks before the missionaries were forced to raise wages to their previous level. ${ }^{231}$ Sill argues that when pupils at the mission schools did not like the way they were being treated or they felt that the missionaries" expectations of them were unfair, they resorted to collective complaining and negotiating in order to achieve more desirable conditions. When they did not get the result they were hoping for, many of them simply ran away. ${ }^{232}$ "Revolts" like these were undertaken by both male and female children, but it is unclear the extent to which girls left the boarding schools in groups the way that boys did. Nevertheless, by the end of 1861, almost one third of the pupils at the Aburi boarding school had left. According to the housefather,

\footnotetext{
${ }^{229}$ BM Series D-12, Reel 129 (1876).

${ }^{230}$ BM Series D-12, Reel 129 (1876).

${ }^{231}$ BM Series D-12, Reel 129 (1876). Through their invocation of E. P. Thompson's work, Africanist labor historians have stressed that class formation did, in fact, occur in Africa and that, African workers, as a collective, were influential in mediating colonial capitalism. In the case of Urban South Africa, Zulu notions of time actually "infiltrated" the colonial organization of labor. As Keletso Atkins argues, labor should be seen not as "a strategy of capital, but as a capitalist adaptation to an African work rhythm." (Cooper, "Work, Class and Empire," 235-237) See also: Keletso Atkins, “'Kafir Time': Preindustrial Temporal Concepts and Labour Discipline in Nineteenth-Century Colonial Natal," Journal of African History XXIX (1988). 229-244. \& Frederick Cooper, Plantation Slavery on the East Coast of Africa (New Haven: Yale University Press, 1977).

${ }^{232}$ Sill, Encounters in Quest of Christian Womanhood, 300.
} 
Johannes Stanger, some had run away because they were dissatisfied with the way in which "meals were organized and provided to them." 233 Unfortunately, we have no way of knowing why the children actually left, but it seems safe to assume that there would have been a variety of motives beyond merely the reductive explanation about food and meals offered by the housefather.

The reports in the Basel Mission archive indicate that the missionaries viewed African children's attendance at mission schools as beneficial to the societies they were attempting to shape in Africa. However, many of their actions in colonial Ghana are evidence of a very clear misunderstanding of, or disregard for, existing social, cultural, and economic systems. African parents' request for payment in exchange for their children's attendance at mission schools may have been a response to the degree of control missionaries had attained over their children. It may also have been an attempt to reassert control over their children's labour so that it would benefit the family, rather than the Basel Mission. The request for payment clearly shows that local communities were not completely satisfied with their children's attendance at mission schools and the ensuing loss of the children's labour to the missionaries.

\footnotetext{
${ }^{233}$ Sill, Encounters in Quest of Christian Womanhood, 300. For an in-depth discussion of the practices missionaries attempted to introduce with regard to food preparation and meal service, see Ulrike Sill "Creating a new Female Space: The Basel Mission Girls' Boarding Schools," in Ulrike Sill Encounters in Quest of Christian Womanhood: The Basel Mission in Pre- and Early Colonial Ghana, (Boston: Brill \& Leiden, 2010).
} 


\section{Labour and Girlhood}

While African boys attended mission schools and were used as labourers much more commonly than African girls, there were indeed instances in which girls were present as both labourers and pupils. For example, in 1866, five servant girls were pupils at the Akim school where they attended classes in the mornings and learned needlework in the afternoons. ${ }^{234}$ According to Mission reports, "the local women do not know anything about sewing. $" 235$ In an effort to establish familiar European gender roles in Africa, the Basel Mission felt this was an important skill for African girls to learn. In addition, there are some cases of girls being sent to live with missionary families so they could learn the skills that other girls were being taught at boarding schools. Regardless of where the training and education of girls took place, the primary goal was the creation of "proper housewives." 236

Members of the Basel Mission observed that, "apart from smiths and basket weavers, there are no distinct professions in the Gold Coast."237 They reported that what, in Europe, would have been done by "various craftsmen" was being done by ordinary local people. ${ }^{238}$ Moreover, they were surprised when they observed this work (milling, baking, butchery, tailoring, and weaving) was being done primarily by women, in addition to their labours in the home and in the fields. ${ }^{239}$ The missionaries deemed it necessary that, in addition to cleaning, cooking, and agricultural tasks, African girls

\footnotetext{
${ }^{234}$ BM Series D-12, Reel 130 (1866).

${ }^{235}$ BM Series D-12, Reel 129 (1857).

${ }^{236}$ Sill, Encounters in Quest of Christian Womanhood, 292.

${ }^{237}$ BM Series D-12, Reel 129 (1866).

${ }^{238}$ BM Series D-12, Reel 129 (1857).

${ }^{239}$ BM Series D-12, Reel 129 (1857).
} 
should be taught crafts like sewing because it was important to them that girls were able to take care of the mission house and tend to domestic tasks. ${ }^{240}$ In contrast, boys were being trained as "carpenters and masons" and "learning to be sawyers, how to use a plane, and how to cook and backe [sic]."241 In Akropong, male children were responsible for "making a new coffee plantation, and a corn farm" and helping in the construction of a new chapel at the mission station. ${ }^{242}$ Sewing and other needlework was the only aspect of missionary education and training that was exclusively reserved for women and girls. Sill describes it as, "an exception within an otherwise officially male-centered missionary organization. Only women taught it. Women were the major decision makers about which handicrafts were to be taught and about the choice of articles to be produced."243

Sewing and the production of other handicrafts was also a way that girls were able to contribute significantly to the economic sustainability of the mission stations. Boys were expected to do this through the "products of their vocational training," but the dresses and other clothes produced by students at the girls' schools were actually more lucrative than any tasks performed by boys. ${ }^{244}$ In fact, the sale of these items covered ten to fifteen percent of the budgeted costs of operating the mission stations. ${ }^{245}$

Mission reports indicate that, in 1876, there were twelve "strong girls" working at the station because they could not employ men without raising the wages. ${ }^{246}$ The missionaries wanted to establish a girls' school in Begoro but they were "having

\footnotetext{
${ }^{240}$ BM Series D-12, Reel 129 (1857).

${ }^{241}$ BM Series D-12, Reel 130 (1865) \& BM Series D12, Reel 129 (1858).

${ }^{242}$ BM Series D-12, Reel 130 (1882).

${ }^{243}$ Sill, Encounters in Quest of Christian Womanhood, 319.

${ }^{244}$ Sill, Encounters in Quest of Christian Womanhood, 320-321.

245 Sill, Encounters in Quest of Christian Womanhood, 321.

${ }^{246}$ BM Series D-12, Reel 129 (1876).
} 
difficulty even getting sufficient numbers of girls to work in the house." ${ }^{247}$ The girls who did work in the Begoro mission house usually came from the Kukurantumi region (about 100 kilometres north of Accra) and, according to Basel Mission records, their parents and community leaders were often reluctant to allow them to work at the mission station. In the missionaries' view, this anxiety stemmed from a situation in which two African girls had been given instruction in the Church and then refused to marry "heathens." 248 While it is clear that the relationship between African families and the Basel Missionaries was always tenuous, the missionaries seem to have had more success convincing parents to send their boys, rather than their girls, to work and school at the mission station.

The missionaries were also having trouble recruiting girls to come to the school in Fankyeneko, about thirty kilometres further north. According to missionary reports, African girls were required, by their families, to mind younger siblings and community members, as well as help with domestic tasks such as cooking. The missionaries believed that these responsibilities made African girls less likely to attend mission school than their male counterparts. ${ }^{249}$ This suggests that, because of existing African social and cultural norms, the Basel Missionaries were able to more effectively utilize the labour of African boys than that of African girls. African boys were more likely to be involved in seasonal work such as collecting snails, harvesting palm oil, and agricultural and trade-

\footnotetext{
${ }^{247}$ BM Series D-12, Reel 129 (1880).

${ }^{248}$ BM Series D-12, Reel $129(1880)$.

${ }^{249}$ BM Series D-12, Reel 129 (1880).
} 
related work. This enabled them to attend school at the mission stations more regularly than African girls who were responsible for daily domestic tasks. ${ }^{250}$

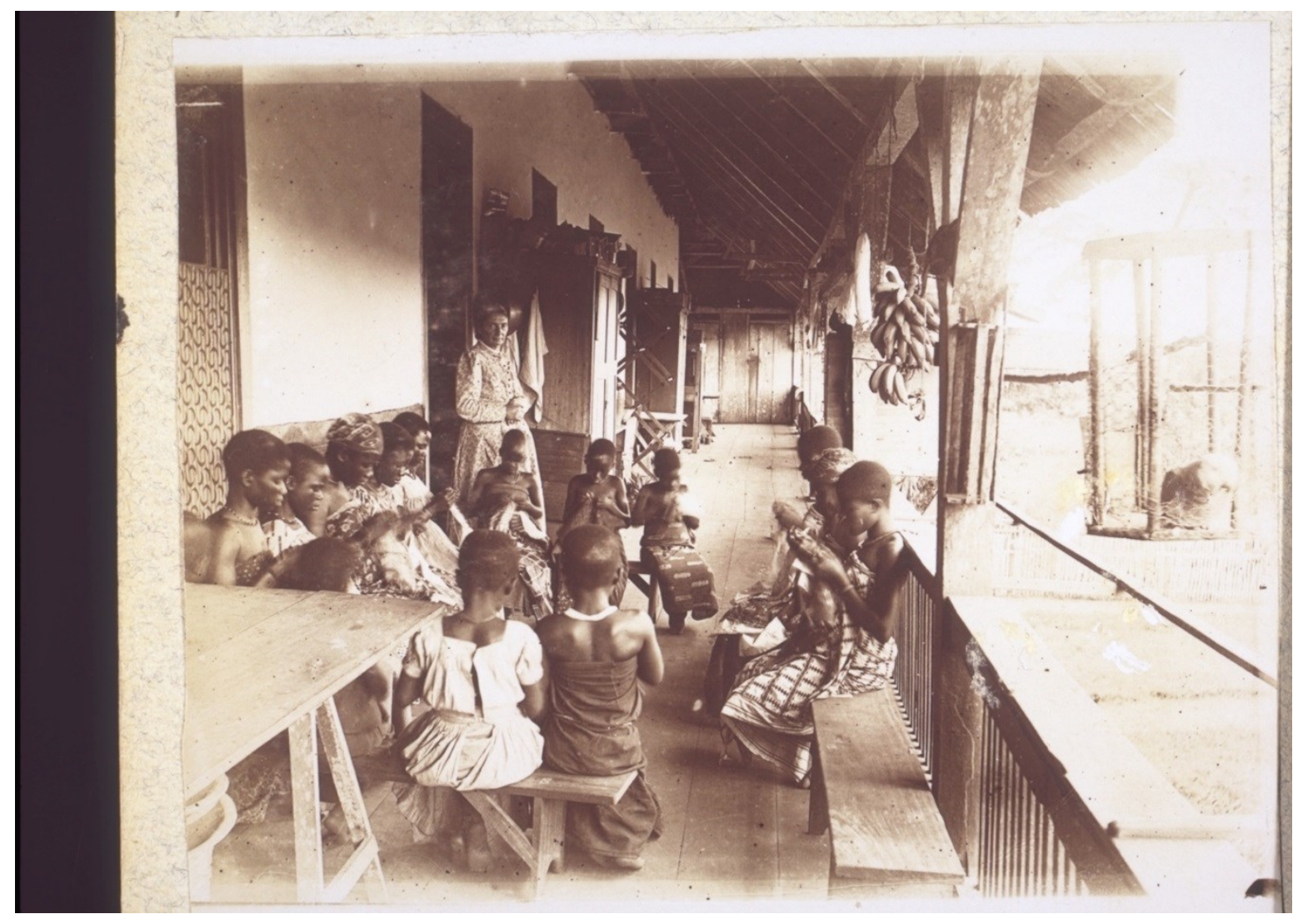

[photo caption: "Sewing school on a veranda in Abetifi. Along the railing a bunch of bananas and a parrot in a cage," c. $\left.1888-1896 .^{251}\right]$

Ulrike Sill argues that the establishment of missionary boarding schools in precolonial and colonial Ghana created a new space for women and girls in which European

\footnotetext{
${ }^{250}$ BM Series D-12, Reel 129 (1880).

${ }^{251}$ Basel Mission Archives / Basel Mission Holdings, QD-30-044.0199. Taken by Louis August Friedrich Ramseyer c. 1896-1906 in Ghana.
} 
notions of femininity and domesticity could be instilled in African girls. ${ }^{252}$ Girls' education involved school lessons and daily household chores and instruction in the creation of handicrafts was very important in the over-all missionary education of girls.

The mission records do not always specify who was responsible for teaching sewing and other skills to girls, but photographs of the Basel Mission's experience in colonial Ghana indicate that female members of the mission, often the wives of missionaries, filled this role. According to Sill, senior missionary women would have been suitable teachers to impart skills like knitting and sewing upon African girls because they were the "embodiment of the norms, values, skills, knowledge, attitudes, and deportment to be passed on." 253 The gendering of education and training reflects European conceptions of labour division based on gender roles that were not necessarily reflective of African ideas and practices. As indicated above, the Basel missionaries were aware that African women were responsible for a great deal of work that, in Europe, would have been done by male tradespeople. Rather than incorporating these native practices, the missionaries made a concerted effort to re-construct gender roles in a way that more closely resembled those firmly entrenched in European society.

Handicrafts, such as needlework and sewing, were regarded by the missionaries as appropriate work for women and girls. The missionaries believed that the development of skills in this area was necessary for women who desired to be seen as living up "to what was considered their proper vocation." 254 According to Paul Jenkins,

${ }^{252}$ Sill, Encounters in Quest of Christian Womanhood, 287.

${ }^{253}$ Sill, Encounters in Quest for Christian Womanhood, 289.

${ }^{254}$ Sill, Encounters in Quest for Christian Womanhood, 310. 
hand work classes for African girls were usually held on the verandas of mission houses. The skills of sewing, crocheting, and mending were essential to the task of dress-making, which was performed only by women and girls and sewing classes were an important aspect of the Basel Mission school curriculum. ${ }^{255}$

Jenkins argues that the Basel Mission created a demand for clothing by setting new standards of dress for women in both public and domestic spaces. ${ }^{256}$ For example, the provisional regulations of 1852 stated that women had to cover their breasts, while bare-chested, or partially bare-chested men do not seem to have been controlled in this manner. ${ }^{257}$ The missionaries also created new occasions for which they expected African women and girls to take extra care with the way they looked and dressed, in particular their attendance at the institutions of church and school. Through the entrenchment of school and church as everyday institutions, the fashion of women and girls was transformed to reflect European standards. ${ }^{258}$ Thus, according to Jenkins, the missionaries created an increased demand for women's clothing, while also shaping an exclusively female profession that catered to this new demand, situating women and girls in a role that was much more familiar to Europeans. This transformation of women's clothing was also important to the broader civilizing mission of the Basel Mission in that standards of dress for African women and girls were being determined by what was deemed appropriate for their attendance at church and school. Photographs taken by

\footnotetext{
${ }^{255}$ Paul Jenkins, "Everyday Life Encapsulated? Two Photographs Concerning Women and the Basel Mission in West Africa, c. 1900," Journal of African Cultural Studies 15, (June 2002) 45-60. 46-51. \& Sill, Encounters in Quest for Christian Womanhood, 310.

${ }^{256}$ Jenkins, "Everyday Life Encapsulated?" 55.

${ }^{257}$ Sill, Encounters in Quest of Christian Womanhood, 314.

${ }^{258}$ Jenkins, "Everyday Life Encapsulated?" 55.
} 
members of the Basel Mission suggest that outside of school and church, women and girls often wore traditional clothing over European style dresses. Sill argues that while missionaries did not insist upon African women wearing European-style clothing, they did demand that "body parts described as "private parts' should be covered."259 This did apply to men and women, but there was significantly more regulation when it came to women and girls. $^{260}$

European missionary societies played an important role in the greater imperial and colonial "project." Missionaries "viewed colonialism and capitalism as providing new opportunities to bring civilization and Christianity to backward populations" and "colonialism instilled in missionaries a tremendous confidence and allowed them to travel to once-inhospitable lands."261 Missionaries relied on the colonial state to provide them with security and protection, but when it came to financing their colonial operations, they were dependent upon the donations of European parishioners and profits they made from agricultural and manufacturing ventures in the colonies. Ideologically, evangelical mission societies were fundamentally against slavery in all its forms. However, the missionaries sometimes relied on unpaid labour in order to ensure the economic stability of their African initiatives.

\footnotetext{
${ }^{259}$ Sill, Encounters in Quest of Christian Womanhood, 316.

${ }^{260}$ Sill, Encounters in Quest of Christian Womanhood, 316.

${ }^{261}$ Barnett, Empire of Humanity, Chapter 3, 57-75.
} 
In the case of the Basel Mission, children played an important role in African congregations as both converts and labourers. They were trained in various trades that could benefit the mission financially and ensure its sustainability in the colony. The "civilizing mission" would have been impossible if the mission was not financially successful and this financial success was often dependent upon the labour of children and youth. This often meant altering social, cultural, and political conventions and subverting existing gender roles in order to separate children from their families and to solidify the Mission's control of African children and their labour. As a result, children became more closely connected to the Basel Mission as labourers and remained bound to the mission and the church throughout their youth and into adulthood. However, this control was not always easily achieved. In some cases, working children and youth at mission stations organized themselves and participated in labour strikes. The Basel Mission also had to compete with African parents and communities for control over children and in some cases children rebelled against the missionaries and took control of their own labour. 


\section{Conclusion}

In 1874, slavery, as a legal category, was abolished and the buying and selling of slaves in colonial Ghana was declared illegal. However, slavery did not officially end in the colony until well after the First World War. League of Nations inquiries in the 1920s and the establishment of an anti-slavery committee in the 1930s caused the colonial state to revisit its policies regarding slavery. ${ }^{262}$ Since then, slavery and forced labour have continued to exist in Ghana as well as in many other areas of the world.

A 2010 BBC Panorama news video covers the story of a twelve year old boy named Fatao. $B B C$ reporters found the boy working on a cocoa farm in Ghana. They were told by other workers that Fatao had no family, his parents were killed and he was being taken care of at the farm. He was forced to work long days harvesting cocoa pods with a machete and he was told not to speak with the reporters. Fatao, who is from Burkina Faso, was sold to a child trafficker by his uncle and taken to Ghana where he worked for no pay. His mother, whom they managed to track down in Burkina Faso, tells the $B B C$ reporter that she left her son with his uncle when she went to visit her sister so that he could go to school. When she returned Fatao had been sold. ${ }^{263}$

The Food Empowerment Project suggests that most cocoa farmers in West Africa earn about two dollars per day and they resort to child labour and child slavery to keep

\footnotetext{
${ }^{262}$ Miers and Roberts "The End of Slavery," 24-25. Article 2 of the 1926 Slavery Convention required that state governments "prevent and suppress the slave trade" and "bring about, progressively and as soon as possible the complete abolition of slavery in all its forms. (Richard Roberts, "The End of Slavery, "Crisis" over Trafficking, and the Colonial State in the French Soudan." In Trafficking in Slavery's Wake: Law and the Experience of Women and Children, edited by Benjamin N. Lawrance and Richard Roberts, (Athens, OH: Ohio University Press, 2012), 67).

263 "Cocoa Slave tastes sweet freedom." BBC Panorama 24 Mar. 2010: Africa.
} 
their cocoa prices competitive. ${ }^{264}$ Many children in the region live in poverty and they start working at a young age in order to help support their families. Some of these children voluntarily leave their families to work on cocoa farms because of the prospect of earning more money than they can at home, others are sold to traffickers, and some are abducted from neighbouring countries like Burkina Faso and Mali. When these children arrive in Ghana or Côte d'Ivoire they are forced to work long days, sometimes using dangerous equipment and hazardous chemicals and pesticides. If they do not work fast enough, they are subject to beatings and other forms of violence. Most of these children do not attend school and in many cases they have no access to clean water or nutritious food. ${ }^{265}$ Over the last decade, the international media has covered a number of stories related to the global cocoa sector and condemned West Africa's cocoa farms as being in violation of the International Labour Organization's (ILO) Child Labour Standards. ${ }^{266}$

Young children in West Africa, like Fatao, who are taken away from their homes generally have little to no idea where they are from and, thus, they become completely dependent on their captors and their masters. If they wanted to run away, regardless of the reason, they would not even know where to go. ${ }^{267}$ Mike Dottridge, former director of Anti-Slavery International, argues that it can be difficult to determine what actually constitutes child slavery and to prosecute those responsible. This is because, in most

\footnotetext{
264 "Child Labor and Slavery in the Chocolate Industry," Food Empowerment Project, 2014 http://www.foodispower.org/slavery-chocolate/

265 "Child Labor and Slavery in the Chocolate Industry," Food Empowerment Project, 2014 http://www.foodispower.org/slavery-chocolate/

${ }^{266}$ ILO, January 26, 2000. "Convention 182." http://www.ilo.org/public/english/standards/relm/ilc/ilc87/com-chic.htm

${ }^{267}$ Mike Dottridge, "Contemporary Child Slavery." In Slaves in the Modern World, edited by Gwynn Campbell, Suzanne Miers and Joseph C. Miller, (Athens, OH: Ohio University Press, 2011). 256.
} 
countries, the mechanisms and processes through which "slavers" would have been prosecuted and punished no longer exist. In addition to the legal hurdles, there is a significant degree of confusion generated by exaggerated claims of journalists and children's rights activists which can make it difficult to determine who is, in fact, a slave. $^{268}$

The extent of forced labour in Africa is difficult to measure. However, what is certain is that the trafficking of women and children affects all contemporary West African countries and the systems through which they are bought and sold are transcontinental in their reach. ${ }^{269}$ What is often missing from the discussion of slavery and coerced labour in the contemporary world is the historical context out of which the "modern" slave trade evolved. Benjamin Lawrance and Richard Roberts have attempted to place the contemporary trade in people in historical context by studying connections between the legacies of imperial conquest and colonial rule, anti-slavery legislation, and the development of international protocols that have sought to put an end to the continued trafficking of vulnerable people, namely women and children. ${ }^{270}$

The historicization of the contemporary issue of child slavery is important, however, as Frederick Cooper points out, searching through history for the origins of today's problems can sometimes result in looking at history in an "ahistorical" manner. This is particularly important when making arguments about the legacies of colonialism.

\footnotetext{
${ }^{268}$ Dottridge, "Contemporary Child Slavery," 256.

${ }^{269}$ Benjamin N. Lawrance and Richard Roberts, "Contextualizing Trafficking in Women and Children in Africa." In Trafficking in Slavery's Wake: Law and the Experience of Women and Children, edited by Benjamin N. Lawrance and Richard Roberts, (Athens, OH: Ohio University Press, 2012). 15.

${ }^{270}$ Benjamin N. Lawrance and Richard Roberts, "Contextualizing Trafficking," 2-3.
} 
What Cooper terms "leapfrogging legacies" is the tendency of scholars to claim "that something at time $\mathrm{A}$ caused something in time $\mathrm{C}$ without considering time $\mathrm{B} .{ }^{, 271} \mathrm{~A}$ "direct and causal connection" between colonial policy implemented in the late nineteenth century can offer some insight, or provide historical context, but it cannot be said to have directly caused the problem of child trafficking and forced labour today. ${ }^{272}$

That being said, any discussion of present-day slavery should attempt to offer some historical context that can be used, not to explain its existence, but to complicate the narrative. In West Africa, the "legislative abolition of the slave trade did not stop the trafficking in people." ${ }^{273}$ Various systems through which people were bought and sold developed in tandem with the transatlantic slave trade and they did not end when that particular slave trade was abolished. The great irony of the campaign to abolish the slave trade is that it actually led to the expansion of slavery in West Africa. The enslavement of adults, particularly adult men, declined, but during the colonial period, communities who were dependent upon forced labour expanded their use of child labourers. ${ }^{274}$

Michael Barnett describes the antislavery movement as a "historic breaching of established categories of humanity."275 $\mathrm{He}$ argues that British public opinion was overwhelmingly sympathetic toward slave emancipation and people believed that Britain's obligation, as an imperial power, went further than simply abolishing slavery.

\footnotetext{
${ }^{271}$ Frederick Cooper, "Postcolonial Studies and the Study of History," 405. Cooper also warns against "story plucking" and "time flattening." Story plucking refers to the extraction of "tidbits from different times and places and treating them as a body independent of their historical relationship, context, or countervailing tendencies." Time flattening "refers to the assumption that a certain essence characterizes a long period of time, passing over the conflict and change within it."

${ }^{272}$ Cooper, "Postcolonial Studies," 405-406.

${ }^{273}$ Lawrance and Roberts, "Contextualizing Trafficking," 3.

${ }^{274}$ Lawrance and Roberts, "Contextualizing Trafficking," 8-9.

${ }^{275}$ Barnett, Imperial Humanitarianism, Chapter 3, 57-75.
} 
They also felt responsible for bringing "civilization" to colonized peoples. ${ }^{276}$ All Europeans powers publicly supported anti-slavery ideals and used the rhetoric of abolitionist ideology to justify conquest and colonialism, but few colonial powers had the ability or the desire to suppress slavery and the slave trade within their colonies. ${ }^{277}$

In colonial Soudan, French officials implemented laws related to slavery and slave-trading because of pressure from the French public, but there was a significant amount of contradiction between policy and practice. Richard Roberts argues that the French colonial government in Soudan had a limited ability to "broadcast" its power beyond the colonial capital and district headquarters. ${ }^{278}$ This meant that regardless of what kind of policy the colonial state enacted, administration of the law suffered because of the state's inadequate capacity to broadcast its power and actually implement policies throughout the colony. ${ }^{279}$

The response of slave dealers in the Soudan was similar to that of traders in British West Africa. In colonial Ghana, anti-slavery laws outlawed the slave trade and afforded slaves the opportunity to self-liberate, but traders simply began to import child slaves from northern regions that were outside formal British jurisdiction. Only the most determined slave children were actually able to liberate themselves. Most child slaves were disguised as the children of their captors and masters. ${ }^{280}$ In response to anti-slavery policy in the French Soudan, traders simply moved away from central areas of the colony

\footnotetext{
${ }^{276}$ Barnett, Imperial Humanitarianism, Chapter 3, 57-75.

${ }^{277}$ Miers and Roberts "The End of Slavery," 7. \& Richard Roberts, "Crisis' over Trafficking," 66.

278 Roberts, "Crisis' over Trafficking," 67.

${ }^{279}$ Roberts, "“Crisis over Trafficking," 67.

${ }^{280}$ Getz, "British Magistrates and Unfree Children," 162.
} 
and disguised slaves as their wives, children, and family in order to avoid punishment. ${ }^{281}$ As a result of its limited ability to broadcast its power, very little was actually done to end the slave trade in the Soudan.

For example, the abolition of "the slave" as a category in 1903 simply meant that masters were no longer able to appeal to the French colonial state to have their slaves returned to them if they ran away. ${ }^{282}$ As it had in colonial Ghana, the elimination of "slave" as a legal category led to a change in the demographics of enslaved peoples in Soudan. Prior to the enactment of anti-slavery laws, adult males represented the majority of trafficked people, but following the implementation of slave trade laws, children began to be targeted more aggressively. ${ }^{283}$

The elimination of the legal category of slave in British and French colonies in West Africa affected children more than any other group. ${ }^{284}$ Adult slaves were able to liberate themselves, but slave children, in particular the very young, would rarely have known the difference between "slave" and "free" and seeking freedom on their own was extremely difficult. ${ }^{285}$ Thus, while the legal designation of "slave" ceased to exist, countless numbers of children continued to be trafficked and enslaved. Just as they do

\footnotetext{
${ }^{281}$ Roberts, "“Crisis over Trafficking," 67-68.

${ }^{282}$ Roberts, "“Crisis over Trafficking," 69.

${ }^{283}$ Roberts, "“Crisis over Trafficking," 67-68.

${ }^{284}$ Women also represented a vulnerable group that was also taken advantage of by slave traders after the implementation of anti-slavery legislation, but adult women often had more opportunities to self-liberate. See: Lawrance and Roberts Trafficking in Slavery's Wake."

${ }^{285}$ Kwabena Adu-Boahen, "Post-Emancipation Slave Commerce: Increasing Child Slave Trafficking and Women's Agency in Late Nineteenth Century Ghana," Lagos History Review 9 (2009) 118-137. 127.
} 
today, nineteenth and early-twentieth century humanitarian organizations lobbied to abolish slavery completely and to free African children who were being held as slaves. ${ }^{286}$ In the opinion of European abolitionists and humanitarians, slaves possessed humanity, but were certainly not equal to white European Christians. They attributed the perceived inferiority of Africans to their environment. In particular, they felt that "race, religion, superstition, and lack of education" contributed to the absence of civilization in the colonies. Thus, the attitude of imperial humanitarians was that slaves should not be liberated without also being civilized. ${ }^{287}$ During this period, abolition movements were closely linked to missionary societies. William Wilberforce argued that, "slavery was a sin against Christianity and that Christianity could civilize the liberated slaves."288

Using evolutionary theories that were popular at the time, missionaries stationed in West Africa attempted to change the environment in which Africans lived by introducing schools, medical clinics, and European-style farms. They also preached selfcontrol and discipline with regard to chastity, sobriety and hard work. ${ }^{289}$ The Basel Mission advocated for the establishment for separate villages for Africans who converted to Christianity. They worried that if African children were exposed to non-Christian practices they would not be raised "properly" and their efforts to civilize and Christianize Africa would be compromised. ${ }^{290}$

The effort of mission societies to civilize the local population was supported by colonial officials because, if missionaries were successful, Africans became more

\footnotetext{
${ }^{286}$ British Parliamentary Papers, May 1891, C-6354.

${ }^{287}$ Barnett, Imperial Humanitarianism, Chapter 3, 57-75.

${ }^{288}$ Barnett, Imperial Humanitarianism, Chapter 3, 57-75.

289 Barnett, Imperial Humanitarianism, Chapter 3, 57-75.

${ }^{290}$ BM Series D-12, Reel 129 (1880).
} 
"compliant, easier to control, and develop tastes and values that were consistent with the interests if the West. ${ }^{291}$ Despite the colonial state's support of missionary efforts, the two did not always agree when it came to anti-slavery policy. Missionaries wanted to emancipate all enslaved peoples, but the colonial state valued profit and stability over abolitionist ideology and evangelical notions of the unity of humanity. ${ }^{292}$

The Basel Missionaries struggled with this throughout their time in colonial Ghana. In their correspondence records, there are references to instances in which missionaries reported cases of slave-trading to colonial officials who either looked the other way or returned the trafficked children without imposing any punishment on those responsible. ${ }^{293}$ Despite its public denunciation of slavery and the enactment of anti-slave trade legislation, the colonial administration made no real attempt to liberate slaves in the colony. ${ }^{294}$ The Basel missionaries also struggled with the idea of purchasing child slaves in order to free them from their masters and creating a kind of "refuge" at the mission stations. This proposal was rejected, however, because of concern that the missionaries' purchase of children would, in fact, stimulate the trafficking of child slaves rather than help to end it. ${ }^{295}$ As much as the Basel missionaries, and other evangelical mission groups, were ideologically opposed to slavery in the colonies, they were dependent upon the colonial state to provide them with security and protection when necessary. ${ }^{296}$ The mission was also dependent upon the production of agricultural and manufactured goods

\footnotetext{
${ }^{291}$ Barnett, Imperial Humanitarianism, Chapter 3, 57-75.

${ }^{292}$ Barnett, Imperial Humanitarianism, Chapter 3, 57-75.

${ }^{293}$ BM Series D-12, Reel 130 (1895).

${ }^{294}$ Getz, "British Magistrates and Unfree Children," 162.

${ }^{295}$ BM Series D-12, Reel 130 (1893).

${ }^{296}$ Barnett, Imperial Humanitarianism, Chapter 3, 57-75.
} 
for economic stability. This meant that they could not push the colonial state as hard as they may have liked and that they themselves were dependent upon the forced labour of African children.

The desire of the colonial state to ensure that the colony remained both stable and profitable, and the missionaries' pragmatic approach to child slavery meant that the issue of child trafficking and forced labour persisted well into the colonial period in West Africa. In colonial Ghana, the experience of enslaved children was certainly a varied one. In some cases children were sent to school and treated as part of the family and if they were given the choice, some did refuse to be emancipated. ${ }^{297}$ However, the enslavement of children often involved violence and abuse. If these cases were brought before colonial officials, they were much more likely to prosecute the abuse than the holding of children as slaves. ${ }^{298}$ In most of West Africa, overt forms of trafficking and slavery declined significantly. As a result of pressure from humanitarian groups and the ambivalence of colonial administrations, the slave trade was forced largely underground and it became more difficult to prosecute. ${ }^{299}$

Mike Dottridge suggests that when dealing with contemporary child trafficking, it is sometimes difficult to determine who is a slave. This is, at least in part, because the differences in conceptions of childhood that exist throughout the world. As James and James have argued, there is not one definition of childhood, nor is there one way in which children experience being a child. There are, instead, a multiplicity of childhoods that

\footnotetext{
${ }^{297}$ Getz, "British Magistrates and Unfree Children," 165.

${ }^{298}$ Getz, "British Magistrates and Unfree Children," 165.

${ }^{299}$ Roberts, “'Crisis' in Trafficking,” 80.
} 
vary over both time and space. International non-governmental organizations have attempted to define terms like "child" and "child labour," but there remains a great deal of gray area involved in definitively labeling children as being involved in the "worst forms of child labour.",300

Determining what actually constituted slavery was also an issue in colonial Ghana. The views of officials charged with the administration of anti-slavery laws were shaped by the British experience; in particular the British tradition of the apprenticeship of children. It was common that "children of the working and impoverished classes of both rural and urban Britons carried out numerous domestic and other chores, often playing a vital economic role in maintaining the household economy."301 Complicating this further was the fact that children who may have been slaves in colonial Ghana were presented as "fosters," a traditional system that Europeans did not understand and fell in a "gray area" that was rarely interfered with by the colonial state. ${ }^{302}$ In Britain, policy and law makers were not focussed on eliminating child labour altogether, but rather on improving the conditions of working children. ${ }^{303}$ These imported moral sensibilities and notions about children, childhood, and race afforded slave traders the ability to disguise trafficked children as apprentices and fosters and allowed them to escape prosecution.

\footnotetext{
${ }^{300}$ Dottridge, “Contemporary Child Slavery," James and James, Constructing Childhood, and Article 3(d) of ILO Convention 182, "The Worst Forms of Child Labour Convention." http://ilo/public/english/standards/ipec/ratification/convention/text.htm

${ }^{301}$ Getz, "British Magistrates and Unfree Children," 160.

302 Coe, "How Debt Became Care," 299. Fosterage was most often practiced by women. They gave their children to other women to raise and take care of for a variety of reasons, including poverty.

${ }^{303}$ Getz, "British Magistrates and Unfree Children," 161.
} 
Michael Barnett argues that "the age of European exploitation and conquest forced the powerful to contemplate their relationship to local populations." 304 Missionaries and humanitarians saw their relationship with Africans as one of "unapologetic paternalism" through which they could bring "colonialism, Christianity and commerce" to Africa. ${ }^{305}$ The colonial state publicly espoused the principles of abolitionist ideology, but a policy of out-right abolition was not in their best interest because it would have caused a labour shortage, thus threatening the stability and productivity of the colony. ${ }^{306}$ In some cases, the ambivalence of colonial powers played an active role in the stimulation of illegal trafficking. For example, in Soudan, the French military actually encouraged the slave trade. French soldiers often retained one or two slaves to perform domestic labour and they often gave slaves to people who were loyal to them. ${ }^{307}$ In colonial Ghana, colonial administrators refuted the claims of Basel Mission members that "little children... two years old upwards" were being trafficked from Salaga, in the north, into the colony. ${ }^{308}$ The trafficking of slaves into the colony became illegal in 1874 , however, it was uncommon for the colonial state to actively pursue slavetraders even when their victims were very young children.

Both missionaries and colonial administrators served to perpetuate and complicate the issues of child labour and child trafficking in the colonies. While public opinion in Europe favoured the full-scale abolition of all enslaved peoples, the priorities of the colonial project were dependent upon access to labour. Anti-slavery laws had caused a

\footnotetext{
${ }^{304}$ Barnett, Imperial Humanitarianism, Chapter 3, 57-75.

${ }^{305}$ Barnett, Imperial Humanitarianism, Chapter 3, 57-75.

${ }^{306}$ Getz, "British Magistrates and Unfree Children," 161-162.

${ }^{307}$ Roberts, "CCrisis' in Trafficking," 71.

${ }^{308}$ Adu-Boahen, "Post-Emancipation Slave Commerce," 125-126.
} 
shift in the demographics of enslaved people making children the primary victims of trafficking and forced labour. The priorities of colonial policy makers ensured the continued existence of child trafficking and child slavery in West Africa and limited the prosecution and punishment of those who violated the law. At times, missionaries acted as the protectors of African children and called attention to instances of exploitation, but at other times they were complicit in this exploitation.

Richard Roberts argues that "the story of slavery and trafficking continues. Women and children remain especially vulnerable to declining economic conditions and to being trafficked. The problems of broadcasting power, interpreting local practices, states' willingness to invoke culture as a defense of inaction, and the episodic nature of political response to humanitarian crises remain barriers to effective enforcement of global human rights regimes." ${ }^{\text {309 }}$ A direct link from the late-nineteenth century to present-day slavery is an 'ahistorical' method through which to explain the issue of contemporary forced labour of children. However, the ambivalence of colonial powers toward the trafficking and enslavement of children has indeed affected the trajectory of slavery and impacted the ways in which children have been vulnerable to traffickers throughout the last one hundred and forty years. The failure of missionaries to recognize the contradictory nature of their use of children as labourers also contributed to their continued exploitation. Through the abolition of the transatlantic slave trade and the enactment of anti-slavery legislation, the institution of slavery was transformed from a

\footnotetext{
${ }^{309}$ Roberts, “'Crisis' in Trafficking," 80.
} 
"legally protected economic activity into an illegal practice."310 This caused slave-traders to target children and forced the entire system of trafficking 'underground.' Thus, the sale of slaves became more difficult to identify and more challenging to prosecute, which is, sadly, where the problem of child slavery and forced labour remains today.

${ }^{310}$ Lawrance and Roberts, "Contextualizing Trafficking," 3. 


\section{References}

\section{Primary Sources}

Anti-slavery and Aborigines Protection Society (Great Britain), Anti-Slavery International, and Adam Matthew Digital (Firm). The Anti-Slavery and Aborigines Protection Society Being the Amalgamation, Effected on 1st July 1909, of the British and Foreign Anti-Slavery Society and the Aborigines Protection Society. (London: Anti-slavery and Aborigines Protection Society, 1909).

Article 3(d) of International Labour Organization convention 182 The Worst Forms of Child Labour Convention. http://ilo/public/english/standards/ipec/ratification/convention/text.htm

Basel Mission Archives / Basel Mission Holdings, QD-32.024.0138. Taken by Rosa Luise Ramseyer-Bontems c. 1896-1906 in Ghana.

Basel Mission Archives / Basel Mission Holdings, QD-30-044.0199. Taken by Louis August Friedrich Ramseyer c. 1896-1906 in Ghana.

British Parliamentary Papers, February 6, 1875 C-1139, C-1140, “Correspondence Relating to the Queens' Jurisdiction on the Gold Coast and the Abolition of Slavery Within the Protectorate."

British Parliamentary Papers, May 1891, C-6354 "Gold Coast Correspondence Respecting the Administration of the Laws Against Slavery in the Gold Coast Colony".

Evangelische Missionsgesellschaft in Basel. The Ghana Archive of the Basel Mission. East Ardsley, Yorkshire : New York, N.Y: EP Microform Ltd. ; Distributed by Clearwater Pub. Co, 1978. 'Abstracts of the Basel Mission Correspondence' Series D-12, compiled by Paul Jenkins.

“Calls to End Child Labour on West Africa's Cocoa Farms.” $B B C$, November 10, 2011, sec. Africa. http://www.bbc.co.uk/news/world-africa-15681986.

"Child Labour Rife in Cocoa Sector." BBC, August 1, 2002, sec. Business. http://news.bbc.co.uk/2/hi/business/2166032.stm.

"Chocolate Companies Blamed for Child Labour." BBC, May 4, 2001, sec. Africa. http://news.bbc.co.uk/2/hi/africa/1311892.stm. 
“Cocoa Farms Still Using Child Labour." BBC, November 10, 2011, sec. Africa. http://www.bbc.co.uk/news/world-africa-15686731.

"Cocoa Slave Tastes Sweet Freedom." BBC, March 24, 2010, sec. Panorama. http://news.bbc.co.uk/panorama/hi/front_page/newsid_8584000/8584847.stm.

"Cocoa's Bitter Child Labour Ties." BBC, March 24, 2010, sec. Panorama. UNICEF, End Child Exploitation: Stop the Traffick! (London: UNICEF UK, 2003).

\section{Secondary Sources}

Adu-Boahen, Kwabena. "Post-Emancipation Slave Commerce: Increasing Child Slave Trafficking and Women's Agency in Late Nineteenth Century Ghana." Lagos History Review 9 (2009): 118-137.

Agbeti, J. Kofi. West African Church History, Christian Missions and Church Foundations: 1482-1919. Leiden, Netherlands: Brill, 1990.

Agbeti, J. Kofi. West African Church History, Christian Missions and Theological Training: 1842-1970. Leiden, Netherlands: Brill, 1991.

Aitken, Stuart C., Ragnhild Lund, and Anne Trine Kjourholt, eds. Global Childhoods: Globalization, Development and Young People. London: Routledge, 2008.

Akurang-Parry, Kwabena O. "Transformations in the Feminization of Unfree Domestic Labor: A Study of Abaawa or Prepubescent Female Servitude in Modern Ghana." International Labor \& Working Class History Fall 2010, no. 78: 28-47.

Alenan, Leena. "Rethinking Childhood." Acta Sociologica 31, no. 1 (1988): 53-67.

Allina, Eric. Slavery by Any Other Name: African Life under Company Rule in Colonial Mozambique. (Reconsiderations in Southern African History.) Charlottesville: University of Virginia Press, 2012.

Allman, Jean Marie. I Will Not Eat Stone: A Women's History of Colonial Asante. Social History of Africa. Portsmouth, NH : Oxford [England] : Cape Town: Heinemann ; J. Currey ; D. Philip, 2000.

Antwi, Daniel J. "The African Factor in Christian Mission to Africa: A Study of Morovian and Basel Mission Initiatives in Ghana." International Review of Mission 87, no. 344 (January 1998): 55-66.

Ariès, Philippe. Centuries of Childhood; a Social History of Family Life. Translated by 
Robert Baldick. New York: Knopf, 1962.

Arondekar, Anjali. "Without a Trace: Sexuality and the Colonial Archive." Journal of the History of Sexuality 14, no. Nos. 1/2 (April 2005): 10-27.

Atkins, Keletso. “'Kafir Time': Preindustrial Temporal Concepts and Labour Discipline in Nineteenth-Century Colonial Natal.” Journal of African History, XXIX (1988), 229-244.

Bales, Kevin. Disposable People: New Slavery in the Global Economy. Rev. ed. with a new preface. Berkeley: University of California Press, 2004.

Bales, Kevin. Ending Slavery: How We Free Today's Slaves. Berkeley: University of California Press, 2007.

Ballantyne, Tony. Orientalism, Racial Theory, and British Colonialism: An Aryan Empire. Cambridge Colonial and Postcolonial Studies. New York: Palgrave, 2001.

Barnett, Michael N. Empire of Humanity: A History of Humanitarianism. Ithaca, N.Y: Cornell University Press, 2011.

Bass, Loretta Elizabeth. Child Labor in Sub-Saharan Africa. Boulder: Lynne Rienner Publishers, 2004.

Batstone, David B. Not for Sale: The Return of the Global Slave Trade--and How We Can Fight It. Rev. ed. New York: HarperOne, 2010.

Berman, Edward H. African Reactions to Missionary Education. Publications of the Center for Education in Africa. New York: Teachers College Press, Teachers College, Columbia University, 1975.

Brown, Carolyn A. and Paul E. Lovejoy. Repercussions of the Atlantic Slave Trade: The Interior of the Bight of the Biafra and the African Diaspora. The Harriet Tubman Series on the African Diaspora. Trenton, NJ: Africa World Press, 2011.

Burton, Antoinette M., ed. Archive Stories: Facts, Fictions, and the Writing of History. Durham N.C.: Duke University Press, 2005.

Campbell, Gwyn, Suzanne Miers, and Joseph Calder Miller, eds. Women and Slavery. Athens: Ohio University Press, 2007.

Campbell, Gwyn, Suzanne Miers, and Joseph Calder Miller, eds. Children in Slavery through the Ages. Athens: Ohio University Press, 2009. 
Campbell, Gwyn, Suzanne Miers, and Joseph Calder Miller, eds. Child Slaves in the Modern World. Athens: Ohio University Press, 2011.

Carmichael, John. African Eldorado: Ghana from Gold Coast to Independence. London: Gerald Duckworth \& Co. Ltd, 1993.

_. "Child Labor and Slavery in the Cocoa Industry." Food Empowerment Project, 2014. http://www.foodispower.org/slavery-chocolate/

Coe, Catie. "How Debt Became Care: Child Pawning and Its Transformations in Akuapem, the Gold Coast, 1874-1929." Africa 82, no. 2 (2012): 287-311.

Cooper, Frederick, ed. Struggle for the City: Migrant Labor, Capital, and the State in Urban Africa. Beverly Hills: Sage Publications, 1983.

Cooper, Frederick. Africa Since 1940: The Past of the Present. New York: Cambridge University Press, 2002.

Cooper, Frederick. "Africa's Pasts and Africa's Historians." Canadian Journal of African Studies 34, no. 2 (2000): 298-336.

Cooper, Frederick. Beyond Slavery: Explorations of Race, Labor, and Citizenship in Postemancipation Societies. Chapel Hill: University of North Carolina Press, 2000.

Cooper, Frederick. Colonialism in Question: Theory, Knowledge, History. Berkeley: University of California Press, 2005.

Cooper, Frederick. "Conflict \& Connection: Rethinking African History." The American Historical Review 99, no. 5 (December 1994): 1516-45.

Cooper, Frederick. "Postcolonial Studies and the Study of History." In Postcolonial Studies \& Beyond, edited by Ania Loomba, Suvir Kaul, Matti Bunzl, Antoinette M. Burton, and Jed Esty, 401-22. Durham N.C.: Duke University Press, 2005.

Cooper, Frederick. Plantation Slavery on the East Coast of Africa. New Haven: Yale University Press, 1977.

Cooper, Frederick, and Ann Laura Stoler, eds. Tensions of Empire: Colonial Cultures in a Bourgeois World. Berkeley, Calif: University of California Press, 1997.

Cooper, Frederick. "Work, Class and Empire: An African Historian's Retrospective on E. P. Thompson," Social History, 20 (May, 1995): 235-241.

Copans Jean, Peter Claus Wolfgang Gutkind, and Robin Cohen, eds. African Labor 
History. Sage Series on African Modernization and Development v.2. Beverly Hills: Sage Publications, 1978.

Corsaro, William A. The Sociology of Childhood. 3rd ed. Sociology for a New Century. Thousand Oaks, Calif: Pine Forge Press, 2011.

Cunningham, Hugh. Children and Childhood in Western Society since 1500. 2nd ed. Studies in Modern History. Harlow, England ; New York: Pearson Longman, 2005 .

Cunningham, Hugh. The Invention of Childhood. London: BBC, 2006.

DeMause, Lloyd. The History of Childhood. New York: Psychohistory Press, 1974.

Deutsch, Jan-Georg. Emancipation without Abolition in German East Africa, c.18441914. Eastern African Studies. Oxford, [England] : Athens, OH: James Currey; Ohio University Press, 2006.

Diptee, Audra A., and Martin A. Klein. "African Childhoods and the Colonial Project." Journal of Family History 35, no. 3 (2010): 3-6.

Evans, Judith L. Children in Africa: A Review of Psychological Research. Publications of the Center for Education in Africa. New York: Teachers College Press, 1970.

Fredrickson, George M. Racism: A Short History. Princeton, N.J: Princeton University Press, 2002.

Freund, Bill. The African Worker. African Society Today. Cambridge; New York: Cambridge University Press, 1988.

Gannon, Margaret. "The Basel Mission Trading Company And British Colonial Policy in the Gold Coast, 1918-1928." The Journal of African History 24, no. 4 (1983): $503-15$.

Getz, Trevor R. Slavery and Reform in West Africa: Toward Emancipation in NineteenthCentury Senegal and the Gold Coast. Western African Studies. Athens; Oxford: Ohio University Press, 2004.

Getz, Trevor R. and Liz Clarke. Abina and the Important Men: A Graphic History. New York: Oxford University Press, 2012.

Getz, Trevor R., ed. African Voices of the Global Past: 1500 to the Present. Boulder, Colorado: Westview Press, A Member of the Perseus Books Group, 2014.

Getz, Trevor R. Modern Imperialism and Colonialism: A Global Perspective. Boston: 
Prentice Hall, 2011.

Greene, Sandra E. West African Narratives of Slavery: Texts from Late Nineteenth-and Early Twentieth-Century Ghana. Bloomington: Indiana University Press, 2011.

Grier, Beverly. "Pawns, Porters, and Petty Traders: Women in the Transition to Cash Crop Agriculture in Colonial Ghana.” Signs 17, no. 2 (Winter 1992): 304-28.

Grier, Beverly. Invisible Hands: Child Labor and the State in Colonial Zimbabwe. Social History of Africa Series. Portsmouth, NH: Heinemann, 2006.

Grier, Beverly. "Struggles over African Childhood: Child and Adolescent Labor, 18902920." In The Global History of Childhood Reader, edited by Heidi Morrison. New York, N.Y.: Routledge, 2012.

Haenger, Peter. Slaves and Slave Holders on the Gold Coast: Towards an Understanding of Social Bondage in West Africa. English ed. Basel: Schlettwein, 2000.

Harlow, Barbara and Mia Carter. Imperialism \& Orientalism: A Documentary Sourcebook. Malden, Mass., USA: Blackwell Publishers, 1999.

Helgren, Jennifer, and Colleen A. Vasconcellos. Girlhood: A Global History. The Rutgers Series in Childhood Studies. New Brunswick, N.J: Rutgers University Press, 2010.

Hendrick, Henry. "Children \& Childhood." Journal of the Economic History Society 15 (Autumn 1992): 1-4.

Higgs, Catherine. Chocolate Islands: Cocoa, Slavery, and Colonial Africa. 1st ed. Athens, Ohio: Ohio University Press, 2012.

Hill, Polly. The Migrant Cocoa-Farmers of Southern Ghana; a Study in Rural Capitalism. Cambridge UK: Cambridge University Press, 1963.

Hindman, Hugh D., editor. The World of Child Labour: An Historical and Regional Survey. Armonk, N.Y.: M.E. Sharpe, 2009.

Humphries, Jane. Childhood and Child Labour in the British Industrial Revolution. Cambridge Studies in Economic History. Cambridge, UK; New York: Cambridge University Press, 2010.

James, Allison, and Adrian L. James. Constructing Childhood: Theory, Policy, and Social Practice. Houndmills, Basingstoke, Hampshire ; New York: Palgrave Macmillan, 2004. 
James, Allison, Chris Jenks, and Alan Prout. Theorizing Childhood. Cambridge, UK: Polity Press in association with Blackwell Publishers Ltd, 1998.

James, Allison, and Alan Prout. Constructing and Reconstructing Childhood: Contemporary Issues in the Sociological Study of Childhood. London; New York: Falmer Press, 1990.

Jenkins, Paul. "Everyday Life Encapsulated? Two Photographs Concerning Women and the Basel Mission in West Africa C. 1900." Journal of African Cultural Studies 15, no. 1 (June 2002): 45-60.

Jenkins, Paul, and Christraud Geary. "Photographs From Africa in the Basel Mission Archive." African Arts 18, no. 4 (August 1985): 56-63.

Jenks, Chris. Childhood. Key Ideas. London; New York: Routledge, 1996.

Kendall, R. Elliott. The End of an Era: Africa and the Missionary. London: S.P.C.K, 1978.

Klein, Martin A. Slavery and French Colonial Rule in West Africa. African Studies Series 94. New York: Cambridge University Press, 1998.

Kroll, Jerome. "The Concept of Childhood in the Middle Ages." Journal of the History of the Behavioral Sciences, 13, No. 4 (October 1977): 384-393.

Lawrance, Benjamin N. and Richard Roberts. Trafficking in Slavery's Wake: Law and the Experience of Women and Children. Athens, OH: Ohio University Press, 2012.

Loomba, Ania, Suvir Kaul, Matti Bunzl, Antoinette Burton, and Jed Esty, eds. Postcolonial Studies and Beyond. Durham, N.C.: Duke University Press, 2005.

Lovejoy, Paul E. Transformations in Slavery: A History of Slavery in Africa. African Studies Series 36. Cambridge; New York: Cambridge University Press, 1983.

Lovejoy, Paul E., and Toyin Falola. Pawnship in Africa: Debt Bondage in Historical Perspective. African Modernization and Development Series. Boulder: Westview Press, 1994.

Maybin, Janet. Childhoods in Context. Childhood 2. Chichester, England; Hoboken, NJ: J. Wiley \& Sons, 2003.

Miers, Suzanne. Britain and the Ending of the Slave Trade. New York: Africana Pub. Corp, 1975.

Miers, Suzanne and Igor Kopytoff, eds. Slavery in Africa: Historical and 
Anthropological Perspectives. Madison: University of Wisconsin Press, 1977.

Miers, Suzanne and Richard Roberts, eds. The End of Slavery in Africa. Madison, Wis: University of Wisconsin Press, 1988.

Miers, Suzanne. Slavery in the Twentieth Century: The Evolution of a Global Problem. Walnut Creek, Calif: AltaMira Press, 2003.

Mizen, Phil, Christopher J. Pole, and Angela Bolton, eds. Hidden Hands: International Perspectives on Children's Work and Labour. Future of Childhood Series. London; New York: Routledge, 2001.

Miller, John. Missionary Zeal and Institutional Control: Organizational Contradictions in the Basel Mission on the Gold Coast, 1828-1917. Wm. B. Eerdmans Publishing Co: Grand Rapids, MI, 2003.

Miller, Joseph C. The Problem of Slavery as History: A Global Approach. New Haven, CT: Yale University Press, 2012.

Morrison, Heidi, ed. The Global History of Childhood Reader. Routledge Readers in History. London; New York: Routledge, 2012.

Nworah, Kenneth D. “The Aborigines' Protection Society, 1889-1909: A Pressure-Group in Colonial Policy." Canadian Journal of African Studies / Revue Canadienne Des Études Africaines 5, no. 1 (January 1, 1971): 79-91.

Off, Carol. Bitter Chocolate: Investigating the Dark Side of the World's Most Seductive Sweet. Toronto: Random House Canada, 2006.

Quartey, Seth. Missionary Practices on the Gold Coast, 1832-1895: Discourse, Gaze \& Gender in the Basel Mission in Pre-Colonial West Africa. Youngstown, NY: Cambria Press, 2007.

Reid, Richard J. A History of Modern Africa: 1800 to the Present. Concise History of the Modern World. Chichester, U.K. ; Malden, MA: Wiley-Blackwell, 2009.

Schmidt, Elizabeth. Peasants, Traders, and Wives: Shona Women in the History of Zimbabwe. Portsmouth, NH: Heinemann, 1992.

Shahar, Shulamith. Childhood in the Middle Ages. London; New York: Routledge, 1990.

Shetty, Parinitha. "Missionary Pedagogy and Christianisation of the Heathens: The Educational Institutions Introduced by the Basel Mission in Mangalore." The Indian Economic and Social History Review 45, no. 4 (2008): 509-51. 
Sill, Ulrike. Encounters in Quest of Christian Womanhood: The Basel Mission in Preand Early Colonial Ghana, (Brill and Leiden: Boston, 2010).

Stern, Peter. Childhood in World History. New York: Routledge, 2006.

Stoler, Ann Laura. Along the Archival Grain: Epistemic Anxieties and Colonial Common Sense. Princeton: Princeton University Press, 2009.

Sutton, Inez. "Labour in Commercial Agriculture in Ghana in the Late Nineteenth and Early Twentieth Centuries." Journal of African History 24, (1983) 461-483.

Thompson, E. P. The Making of the English Working Class. New ed. Harmondsworth: Penguin, 1980.

Thompson, T. Jack. Light on Darkness?: Missionary Photography of Africa in the Nineteenth and Early Twentieth Centuries. Studies in the History of Christian Missions. Grand Rapids, Mich: W.B. Eerdmans Pub. Co, 2012.

Trouillot, Michel-Rolph. Silencing the Past: Power and the Production of History. Boston, Mass: Beacon Press, 1995.

Wells, Karen. Childhood in a Global Perspective. Cambridge, UK ; Malden, MA: Polity Press, 2009.

Wiltgen, Ralph M. Gold Coast Mission History, 1471-1880. Techny, Ill., 1956. 